\title{
Kurumsal Yapının Ekonomik Büyüme Üzerindeki Etkileri: G-20 Ülkeleri Üzerinde Bir Uygulama (1996-2014)
}

\author{
Ömer Yalçınkaya ${ }^{a}$
}

Şekip Yazgan ${ }^{\mathrm{b}}$

\begin{abstract}
Öz: Bu çalışmada, iktisadi büyüme teorilerinin uzun dönemli ekonomik büyümenin temel belirleyicileri konusunda geçirdiği evrimle paralel kurumsal yapının ekonomik büyüme üzerindeki etkileri ekonomik açıdan farklı gelişmişlik düzeyine sahip G-20 ülkeleri üzerinde 1996-2014 dönemi için ekonometrik olarak incelenmektedir. Kurumsal yapının ekonomik büyüme üzerindeki etkilerinin daha tutarlı bir şekilde incelenebilmesi ve sonuçlar özelinden karşılaştırma yapılabilmesi için G-20 ülkeleri ekonomik açıdan gelişmiş G-9 ve gelişmekte olan G-10 ülkeleri olarak iki alt grupta analize dâhil edilmişlerdir. Bu yönüyle çalışmada, G-9 ve G-10 gruplarında yer alan ülkelerin uzun vadeli ekonomik büyüme performanslarının ve ekonomik açıdan gelişmişlik seviyelerinin farklılaşmasında kurumsal yapının etkilerinin değerlendirilmesi amaçlanmıştır. Çalışma sonucunda, inceleme döneminde kurumsal yapı göstergelerinin ekonomik büyüme üzerindeki etkilerinin G-9 grubunda pozitif yönlü ve istatistiki açıdan anlamlı olduğu, buna karşılık G-10 grubunda ise genellikle negatif yönlü ve anlamlı olduğu sonucuna ulaşılmıştır. Bununla birlikte çalışmada, örneklem döneminde G-9 ve G-10 grubunda yer alan ülkelerin, uzun vadeli ekonomik büyüme performanslarının ve gelişmişlik düzeylerinin farklılaşmasında fiziksel-beşeri sermaye birikiminin yanı sıra farklı nitelikteki kurumsal yapılara sahip olunmasının daha fazla etkili olduğunu belirlenmiştir.
\end{abstract}

Anahtar Sözcükler: Sürdürülebilir Büyüme, Kurumsal Yapı, G-20 Ülkeleri, Yeni Nesil Panel Veri Analizi

JEL Sınıflandırması: B22, C49, H00

\section{The Effects of Institutional Structure on Economic Growth: An Application on G-20 Countries (1996-2014)}

Abstract: In parallel to the evolution of the economic growth theories regarding the main indicators of long term economic growth, this article econometrically analyses the long term effects of the institutional structure on the economic growth of G-20 countries with different development levels for the period of 1996-2014. In order to examine the impact of the institutional structure on economic growth more coherently and to compare the results, G-20 countries are included in the analysis under two sub-groups respectively as economically developed G-9 countries and developing G-10 countries. Thus the article aims to evaluate the impact of the institutional structure on the differentiation of the long term economic growth performances and economic development levels of the countries under the groups G-9 and G-10. The article concludes that, effects of the institutional structure indicators on the economic growth have been positive and significant in statistical terms in the sub-group G-9, while they have been usually negative and significant in sub-group G-10 during the period analysed. Nonetheless, the article indicates that, along with the physical and human capital accumulation, possession of different institutional structures are more effective in differentiation of the long term economic growth performances and development levels of the countries in the groups of G-9 and G-10 during the sample period.

Keywords: Sustainable Growth, Institutional Structure, G-20 Countries, New Generation Panel Data Analysis

JEL Classification: B22, C49, H0O

${ }^{a}$ Assist. Prof., PhD., Ağrı İbrahim Çeçen University, Faculty of Economics and Administrative Sciences, Department of Economics, Agri, Turkiye, omeryalcinkaya84@hotmail.com

${ }^{b}$ Assist. Prof., PhD., Ağrı Ibrahim Çeçen University, Faculty of Economics and Administrative Sciences, Department of Economics, Agri, Turkiye, sekipyazgan@hotmail.com 


\section{Giriş}

Ekonomik büyüme kavramı, iktisadi düşüncenin evrimi içerisinde ve birbirini izleyen iktisadi ekollerin her birinde önemli bir yer tutmuş ve iktisadi hayatın hemen her döneminde en çok tartışılan ve araştrılan konuları arasında yer almıştır. Bu doğrultuda tarihsel süreç içerisinde birbiri ardına ortaya konulan iktisadi büyüme teorileri, ülkeler arasındaki ekonomik büyüme ve gelişmişlik/gelir düzeyi farklıklarını içinde bulunulan dönemin koşulları altında açıklamaya çalışmışlardır.

Uzun vadeli ve üretim kapasitesindeki artı̧̧arla ilgili bir kavram olan ekonomik büyüme, ekonominin kurumsal yapısı veri olarak alındığında birey başına düşen üretim faktörlerinin (sermaye, işgücü, doğal kaynaklar vb.) fiziki miktarlarının artması ve/veya ortalama verimliliklerinin yükselmesi gibi temelde iki etkenle meydana gelmektedir. Ekonomik büyümenin ve ülkeler arasındaki büyüme farklılıklarının nedenlerini açıklamaya yönelik olarak geliştirilen geleneksel (Klasik, Keynesyen ve Neo-Klasik) ile modern (i̇çsel) büyüme teorilerinde, ekonomik büyümenin temel belirleyicisi olarak genelde bu iki etken üzerinde durulmakta ve ekonominin kurumsal yapısında meydana gelen gelişmeler dikkate alınmamaktadır.

Bu yönüyle, ekonomik büyüme sürecini sadece iktisadi faktörlerle açıklamaya çalışan Klasik ve Keynesyen büyüme teorilerinin ülkeler arasındaki gelir düzeyi farklııklarını açıklamakta yetersiz kalması, teknolojinin dışsal ve sabit olduğu varsayımı üzerine kurulan Neo-Klasik büyüme modellerinin öngörülerinin de gerçekleşmemesi literatürde yeni büyüme teorilerinin ortaya çıkmasına ortam hazırlamıştır. içsel Büyüme modelleri olarak da ifade edilen bu yeni büyüme teorileriyle birlikte ülkeler arasındaki ekonomik büyüme ve gelir düzeyi farklııkları iktisadi faktörlerin yanı sıra iktisadi olmayan faktörlerle de açıklanmaya çalışıııştır (Berber, 2011: 143). İçsel büyüme teorileriyle birlikte büyüme literatüründe ağırlığı giderek artan kuramsal ve ampirik çalışmalarda, fiziki-beşeri sermaye birikimi, teknolojik gelişme düzeyi, demografik-coğrafi etkenler, gelir dağılımı ve kurumsal yapı gibi iktisadi ve iktisadi olmayan bir dizi faktör ülkeler arasındaki ekonomik büyüme ve gelir düzeyi farklılıklarının temel açıklayıcıları olarak ele alınmaktadır (Kucuker, 2003: 6).

Kurumsal iktisat yaklaşımında ise geleneksel ve modern büyüme teorilerinden farklı olarak ülkeler arasındaki ekonomik büyüme ve gelir düzeyi farklıkları sahip olunan farklı nitelikteki kurumsal yapılarla açıklanmaktadır. Kurumsal iktisada göre, diğer büyüme teorilerinin ekonomik büyümenin belirleyicileri olarak öne sürdüğü iktisadi ve iktisadi olmayan faktörler, ülke ekonomilerinin sahip olduğu kurumların ve kurumsal yapının sağlamış olduğu teşviklerin sonucunda ortaya çıkmaktadır. Bu yönüyle kurumsal iktisatta söz konusu faktörler, ekonomik büyümenin nedeni değil sonucu olarak ele alınmakta ve ülke ekonomilerinin sahip olduğu kurumlar ve kurumsal yapı ekonomik büyüme analizlerinde odaklanılması gereken temel noktayı oluşturmaktadır (Hayaloğlu, 2012: 3).

Öyle ki ülke ekonomilerinde sahip olunan siyasal ve toplumsal ortamın yani kurumsal yapının düzeyi; mülkiyet haklarının sağlamlığı, yolsuzluk algısının düşüklüğü, politik-ekonomik hak ve özgürlüklerin korunması, siyasal istikrarın sağlanması, hukukun üstünlüğü vb. gibi kaynakların etkin kullanımındadağılımında önemli olan unsurları yansıtmaktadır. Bu anlamda etkin bir şekilde işleyen kurumsal yapı, ülke ekonomilerinde kaynak israfinı önleyerek, piyasa aksaklıklarını ortadan kaldırarak, belirsizlikleri azaltıp işlem maliyetlerini düşürerek, pozitif dışsallıklar yaratarak, yatııılar için güvenli bir ortam yaratmakta ve girişimcileri üretken yatırımlara yönlendirmektedir. Diğer bir deyişle, ülke ekonomilerinde uzun vadeli ve sürdürülebilir ekonomik büyüme, ancak ekonomideki kurumların ve kurumsal yapının üretim-yatırım kararlarını teşvik edebildiği ölçüde gerçekleşmektedir (Pamuk, 2014: 40-41). Bu kapsamda, kurumsal iktisat yaklaşımı ile birlikte iktisadi büyüme literatürü, ülkeler arasındaki ekonomik büyüme ve gelir düzeyi farklılıklarının; fiziki ve beşeri sermaye donanımındaki farklııklardan çok, kurumların ve kurumsal yapının kalitesindeki farklııklardan kaynaklandığı noktasına doğru bir gelişme göstermektedir (Kucuker, 2003: 17).

İktisadi büyüme teorilerinin ekonomik büyümenin temel belirleyicileri konusunda geçirdiği evrimle paralel çalışmada kurumsal yapının ekonomik büyüme üzerindeki etkilerinin ekonomik açıdan farkı gelişmişlik düzeyine sahip G-20 ülkeleri üzerinde incelenmesi amaçlanmaktadır. Bu genel amaçla birlikte çalışmada, G-20 grubunda yer alan ülkelerin uzun vadeli ekonomik büyüme performanslarının ve ekonomik açıdan gelişmişlik seviyelerinin farklılaşmasında kurumların ve kurumsal yapının etkilerinin değerlendirilmesi amaçlanmaktadır. Nitekim ülke ekonomilerindeki sosyo-ekonomik yapının temelini kurumların oluşturduğu 
dikkate alındığında, ülkeler arasındaki ekonomik büyüme ve gelişmişlik farklılıklarının faktör birikimi ve/veya üretkenlikteki artışla açıklanamayan bölümünün farklı nitelikteki kurum ve kurumsal yapılara sahip olunması ile açıklanabileceğini düşündürmektedir.

Bu kapsamda girişi takiben ikinci bölümde, kurumsal yapının ekonomik büyüme üzerindeki etkilerini inceleyen teorik ve ampirik literatür ana hatlarıyla özetlenmektedir. Üçüncü bölümde çalışmanın kapsamı açıklanmakta ve çalışmada kullanılan veri seti kısaca tanıtımaktadır. Çalışmanın dördüncü bölümünde, farklı nitelikteki kurumsal yapı değişkenlerinin ekonomik büyüme üzerindeki uzun dönemli etkileri ekonometrik olarak incelenmekte ve çalışma genel bir değerlendirmeyle tamamlanmaktadır.

\section{Teorik Çerçeve ve Ampirik Literatür}

Devletin, iktisadi büyüme için gerekli yasal şartları sağlayan salt bir kurum olarak görüldüğü Klasik büyüme teorilerinde iktisadi büyüme olgusu, temelde sermaye birikimi, tasarruf-yatırım, nüfus artı̧̧ hızı vb. iktisadi değişkenler tarafindan açıklanmaktadır. Serbest piyasa ekonomisi koşulları altında kendiliğinden oluşan ekonomik büyüme süreci, uzun dönemde iktisadi değişkenlerin azalan getirilerine maruz kalmakta ve ekonomiler kaçınılmaz olarak bir durgunluk evresine girmektedirler. Klasik büyüme teorilerinde, iktisadi olmayan değişkenlerin ve özellikle kurumsal faktörlerin ekonomik büyüme üzerindeki etkileri de dikkate alınmadığından, durgunluk evresiyle birlikte ekonomilerdeki büyüme süreçlerinin de sınırlanacağı kabul edilmektedir.

Klasik iktisatçıların uzun dönem durağan durum yaklaşımının etkisi altında şekillenen Keynesyen büyüme teorilerinde devletin, kamu kesimi için emredici ve özel kesim için yönlendirici nitelikteki etkinliğinin bulunduğu varsayılmakta, iktisadi büyüme süreci Harrod-Domar modeli çerçevesinde açıklanmaktadır. Bu yaklaşıma göre, istikrarlı ve dengeli bir ekonomik büyüme süreci için belirli bir yatırım oranı ile gerçekleşen büyüme hızının gereken büyüme hızına eşit olması gerekmektedir. Üretilen mal ve hizmetlerin arz-talep fazlası yaratmadan emilmesi anlamına gelen bu süreç için iktisadi olan tasarruf-yatırım değişkenlerindeki eşitliğinin sağlanması gerekli ve yeterli bir koşul olmaktadır. Keynesyen büyüme teorilerinde devlet, uyguladığı politikalarla üretim-tüketim kararları ve dolayısıyla ekonomik büyüme süreci üzerinde etkili olabilmesine rağmen, devlet politikaları modelde içerilmemekte ve dışşal olarak kabul edilmektedir. Bu nedenle, bu yaklaşımda iktisadi olmayan faktörlerin yanı sıra kurumlar ile kurumsal faktörlerin de büyüme üzerindeki etkileri doğrudan dikkate alınmamaktadır (Arslan, 2007: 1).

Slow-Swan tipi Neo-Klasik büyüme teorilerinde ise iktisadi büyüme süreci, ölçeğe göre sabit getiri, sermayenin azalan marjinal verimliliği, teknolojinin dışsallığı, faktörler arası ikamenin mümkün olması ve bağımsız bir yatırım fonksiyonunun bulunmaması varsayımları altında açıklanmaktadır. Söz konusu varsayımlar çerçevesinde Neo-Klasik büyüme modelinde uzun dönemli veya durağan durum büyüme hızının sıfır olduğu sonucuna ulaşılmakta ve hükümet politikalarının uzun dönemli iktisadi büyüme süreci üzerindeki etkisi oldukça zayıf kalmaktadır. Ancak, modelde dışsal olarak ele alınan teknolojik gelişme düzeyi, sermayenin marjinal verimliliğindeki azalmanın iktisadi büyüme üzerindeki etkisini telafi etmekte ve uzun dönemde sürekli teknolojik gelişme sayesinde pozitif büyüme oranlarına ulaşılabilmektedir. Neo-Klasik büyüme modelinde, uzun dönemli iktisadi büyümenin belirleyicisi olan teknoloji düzeyi modelde içerilmediğinden dışsal olarak belirlenen ve sabit bir hızla artan nüfus, uzun dönemli ekonomik büyümenin temel belirleyicisi olmaktadır. Bununla birlikte, modelde gelişmiş ülkelerden sermayenin getirisinin yüksek olduğu gelişmekte olan ülkelere doğru bir sermaye transferinin olacağı ve böylece farklı gelişmişlik düzeyindeki ülkeler arasında mutlak bir yakınsamasının gerçekleşeceği öngörülmektedir. Ancak süreç içerisinde Neo-Klasik yaklaşımın öngörülerinin gerçekleşmediği, hatta gelişmiş ve gelişmekte olan ülkeler arasındaki gelişmişlik farklılıklarının giderek arttğı görülmektedir. Sonuç olarak, Neo-Klasik büyüme modeli; teknolojik gelişmeyi iktisadi büyüme açısından önemli, ama dışsal olarak kabul etmekte, iktisadi olmayan değişkenlerle kurumsal faktörlerin ekonomik büyüme üzerindeki etkilerini dikkate almamaktadır. Bu yönüyle model, ülkeler arasındaki gelişmişlik/gelir düzeyi farklııklarını açıklamakta yetersiz kalmaktadır(Kibritçioğlu, 1998:8-9). 
Neo-Klasik büyüme teorilerinin öngörülerinin gerçekleşmemesi, alternatif teorileri geliştirerek, ilgili literatürde 1980 'lerin ikinci yarısından itibaren İçsel (yeni) büyüme teorilerinin ortaya çıkmasına ortam hazırladığı görülmektedir. İçsel büyüme teorileriyle ekonomik büyümenin Solow’un öngördüğü şekilde sistemin dışında belirlenen faktörlerle açıklanmaya çalışılan yaklaşımın yerini, ekonomik büyümeyi etkileyen; bilgi, beşeri sermaye, Ar-Ge, teknolojik gelişme, finansal yenilik, devletin rolü ve piyasa yapısı gibi birçok değişkenin sistemin kendi içinde olduğunu öne süren yaklaşımlar almaktadır. Bu yönüyle, İçsel büyüme teorilerinde ekonomik büyümenin kaynakları belirlenmeye çalışılırken, Neo-Klasik yaklaşımın dışsal olarak kabul ettiği unsurlar (nüfus artş̧ hızı ve teknolojik gelişme) içselleştirilmektedir (Berber, 2011: 143-146). Bu yaklaşımda, araştırma ve geliştirme harcamalarından ve beşeri sermaye ile hükümetin teknolojiye yönelik yatırımlarından vb. kaynaklanan taşmaların artan marjinal faktör verimliliği ile ölçeğe göre artan getiri sağlayacağı ve böylece büyüme hızlarının uzun dönemde sıfır olmayacağı kabul edilmektedir (Kibritçioğlu, 1998: 10-16). Özetle, İçsel büyüme teorilerinde, iktisadi büyüme olgusu; fiziki-beşeri sermaye birikimi, Ar-Ge yatırımları, teknolojik gelişme düzeyi, demografik-coğrafi etkenler, kamu harcamaları, gelir dağılımı ve kurumsal yapı gibi iktisadi ve iktisadi olmayan faktörlerle açıklanmaktadır. Ancak, diğer iktisadi büyüme teorilerinde olduğu gibi İçsel büyüme teorisinde de kurumsal yapının ekonomik büyüme üzerindeki etkileri doğrudan dikkate alınmamakta ve kurumsal faktörler modelde dışsal olarak açıklanmaktadır.

20. yy başlarında ortaya çıkan ancak asıl gelişimini 1990 'ların ikinci yarısından itibaren gösteren Kurumsal iktisat yaklaşımında, geleneksel ve modern büyüme teorilerinin aksine, ülkeler arasındaki ekonomik büyüme ve gelişmişlik/gelir düzeyi farklılıklarının açıklanmasındaki en önemli rolü kurumların ve kurumsal yapının oynadığı kabul edilmektedir. Diğer bir deyişle kurumsal iktisat yaklaşımıyla birlikte, uzun dönemli ekonomik büyümenin en önemli belirleyicilerinin iktisadi ve iktisadi olmayan faktörlerden ziyade, ekonomideki kurumların ve kurumsal yapının olduğu görülmektedir. Öncülüğünü Thorstein B. Veblen, John R. Commons ve Wesley C. Mitchell'in yapttğı bu yaklaşıma göre, uzun dönemli iktisadi büyüme ancak kurumsal faktörlerin üretim ve verimlilik artışlarına yol açan ekonomik faaliyetleri istikrarlı bir şekilde desteklemesi ve özendirmesi sayesinde mümkün olmaktadır (Demir, 1996: 64). Çünkü, kurumlar üretim ve yatırım kararlarını özendirmekte, belirsizlikleri azaltarak girişimcilerin bekledikleri getiriyi elde etmelerine olanak sağlamakta ve verimlilik artışlarını mümkün kılarak ekonomik büyüme için teşvik edici bir rol oynamaktadır (North, 2002: 51-73).

Kurumsal iktisat yaklaşıma göre, kurumların ekonomik büyüme üzerindeki teşvik edici etkilerinin gerçekleşebilmesi için ekonomideki kurumların ve kurumsal yapının, toplumdaki geniş kesimlerin üretim ve yatırım kararlarını özendirmesi gerekmektedir. Eğer ekonomideki kurumlar ve kurumsal yapı geniş kesimlerin üretimlerini-yatırımlarını özendirmezse (sadece dar kesimlerin ayrıcalıklı faaliyetlerini özendirirse), fizikibeşeri sermaye birikimde, eğitim seviyesinde, araştırma-geliştirme yatırımlarında, teknoloji düzeyinde vb. bir dizi alanda verimlilik artışlarını sağlayacak yatırımlar gerçekleşmeyecek veya daha sınırlı bir ölçüde gerçekleşecektir (Pamuk, 2013: 38-41). Bu anlamda, iyi ve güçlü nitelikteki kurumların ve kurumsal yapının ekonomik büyüme üzerindeki etkileri pozitif yönlü olurken, kötü ve zayıf nitelikteki kurumların ve kurumsal yapının ekonomik büyüme üzerindeki etkileri negatif yönlü olmaktadır. Kamu görevlilerinin toplumun gelirlerini ve yatırımlarını kendi çıkarları doğrultusunda kullanımının engellenmesi, bireylerin mülkiyet haklarının güvence altına alınması, beşeri sermayenin eğitim yoluyla yenilik yapma, tüketimde rasyonelliği gözetebilecek şekilde yetiştirilmesi vb. unsurlar iyi ve güçlü nitelikteki kurumların ve kurumsal yapının sahip olması gereken başlıca özellikler arasında yer almaktadır (Acemoğlu, 2003: 27).

Diğer taraftan, kurumsal iktisatçılara göre, kurumların ve kurumsal yapının ülkeler arasındaki ekonomik büyüme ve gelir düzeyi farklılıklarının önemli bir açıklayıcısı olarak kabul edilmesinde birbirini tamamlayan muhtemel üç etken bulunmaktadır. Bunlardan birincisi, Neo-Klasik iktisadın ülkeler arasında ekonomik açıdan öngördüğü yakınsama hipotezinin gerçekleşmemesi ve hatta ülkeler arasındaki gelişmişlik/gelir düzeyi farkıııklarının giderek artması iken, ikincisi Sovyet Sosyalist Birliği'nin dağılması ile birlikte ortaya çıkan kurumsal boşluktur. Üçüncüsü ise ülke ekonomilerindeki ulusal gelir düzeyi ile gelir eşitsizliği arasındaki ilişkilerin nerdeyse doğrusallık kazanması, yani belirli bir ulusal gelir düzeyinden sonra gelir dağılımındaki eşitsizliğinin azalmak yerine giderek artmasıdır. Tüm bunların ise büyüme literatüründeki 
ekonomik büyüme analizlerine, kurumsal unsurların da katılmasının arttk ertelenemez bir gereklilik haline getirdiğini ortaya koymasıdır (Uğur, 2011: 36).

Bu bağlamda, kurumsal iktisat yaklaşımı ile birlikte iktisadi büyüme literatüründe ülkeler arasındaki ekonomik büyüme ve gelir düzeyi farklılıklarının açıklanmasında kurumsal unsurlar da giderek artan bir şekilde dikkate alınmaktadır. Ekonomik büyüme ve gelir düzeyi farklııklarının açıklanmasında kurumsal yapı farklılıklarına vurgu yapılması 20. yüzyılın başlarına dayanmakla birlikte kurumsal yapının ekonomik büyüme üzerindeki etkilerini inceleyen öncü çalışmaların özellikle 1990'lı yıllardan itibaren başladığı görülmektedir. İlgili literatürde, bu durumun en önemli nedenleri olarak kurumların/kurumsal yapının tanımlanması ve ölçülmesindeki güçlüklerin yanı sıra kurumsal göstergelerin güvenilir kaynaklardan temin edilebilmesindeki güçlükler olduğu belirtilmektedir. İlgili literatür incelendiğinde, teorik ve ampirik düzeyde yapılan çalışmalarda kurumların ve kurumsal yapının ekonomik büyüme üzerindeki etkilerinin farklı gelişmişlik düzeyindeki ülkelerde ve çeşitli kurumsal yapı değişkenleri kullanılarak incelendiği görülmektedir. Literatürde teorik ve özellikle ampirik düzeyde yapılan çalışmalarda kurumları ve kurumsal yapıyı temsilen; kurumsal kalite, siyasal istikrar, siyasal rejimlerin özellikleri, sosyal sermaye ve sosyal özellikler vb. gibi çeşitli siyasal ve toplumsal göstergeler kullanılmaktadır (Aron, 2000: 100).

Yapılan çalışmalar incelendiğinde, kurumsal kalite göstergesi olarak kullanılan mülkiyet haklarındaki, hukukun üstünlüğündeki ve sözleşmelerin uygulanabilirliğindeki gelişmelerin ekonomik büyüme üzerindeki etkilerinin genellikle pozitif yönlü olduğu sonucuna ulaşılmıştir. (Knack ve Keefer, 1995; Leblang, 1996; Hall ve Jones 1999; Grigorian ve Martinez 2000; Levine vd., 2000; Barro 2002; Acemoğlu vd., 2003; Gökalp ve Baldemir, 2006; Siddiqui ve Ahmed 2010). Kurumsal kalite göstergesi olarak kullanılan yolsuzluk düzeyinin (algısının) yüksekliğinin ekonomik büyüme üzerindeki etkisinin genellikle negatif yönlü olduğu tespit edilmiştir. (Mauro, 1995; Wei 1997; Mauro 1998; Akçay, 2002 Zhang 2005). Buna karşılık, yolsuzluk düzeyinin (algısının) düşüklüğünün ise ekonomik büyüme üzerindeki etkisinin pozitif yönlü olduğu belirlenmiştir. (Tanzi ve Davodi, 1997; Bardhan 1997; Barro 2002; Yapraklı 2008).

Kurumsal yapıyı temsilen siyasal istikrar/istikrarsızlık göstergelerinin kullanıldığı çalışmalarda, siyasal istikrarın/istikrarsızlığın ekonomik büyüme üzerindeki etkisinin sırasıyla pozitif ve negatif yönlü olduğu belirlenmiştir. (Barro, 1991; Devereux ve Wen, 1998; Svensson 1998; Asteriou ve Price, 2000, Gökalp ve Baldemir; 2006; Yapraklı, 2008; Şanlısoy ve Kök 2010). Kurumsal yapıyı, siyasal rejimlerin özellikleri çerçevesinde ekonomik ve politik özgürlük göstergelerini kullanarak inceleyen çalışmalarda ise özgürlüklerin ekonomik büyüme üzerindeki etkisinin genellikle pozitif yönlü olduğu sonucuna ulaşılmıştır. (Scully ve Slottje, 1991; Levine ve Renelt 1992; Abrams ve Lewis, 1993; Easton ve Walker, 1997; Scully 1988; Leschke, 2000; Rodrik, 2000; Scully, 2002; Dawson 2003; Beşkaya ve Manan 2009; Yıldırım 2010; Hayaloğlu, 2012; Zouhaier 2012). Bununla birlikte, kurumsal yapıyı, siyasal rejimlerin demokratik ve anti-demokratik olma özelliklerine göre ayırarak inceleyen çalışmalarda demokratik siyasal rejimlerin ekonomik büyüme üzerindeki etkisinin genellikle pozitif yönlü olduğu tespit edilmiştir. (Abrams ve Lewis, 1993; Helliwell 1994; Leblang 1997; Rodrik 2000; Barro 2002).

Kurumsal yapının ekonomik büyüme üzerindeki etkilerini sosyal sermaye kapsamında inceleyen çalışmalarda, toplumun sosyal ilişkilerinin ve işlemlerinin niteliğini-niceliğini biçimlendiren, ilişkiler, ağlar, normlar ve değerler olarak ifade edilen sosyal sermayenin gelişmişliğinin ekonomik büyüme üzerindeki etkisinin pozitif yönlü olduğu sonucuna ulaşılmıştı. (Knack ve Keefer, 1997; Whiteley, 2000; Beugelsdijk ve Schaik, 2003). Son olarak, kurumsal yapının ekonomik büyüme üzerindeki etkilerini sosyal özellik göstergeleri ile inceleyen çalışmalarda ise tarihsel, dinsel, etnik vb. unsurlardaki farklılıkların, ekonomik büyüme üzerindeki etkilerinin genellikle negatif yönlü olduğu tespit edilmiştir. (Alesina ve Perotti 1994; Levine 1997; La Porta vd., 1998).

Kurumların ve kurumsal yapının ekonomik büyüme üzerindeki etkilerini araşttran literatür bir bütün olarak incelendiğinde, genellikle yatay kesit ve panel veri analizi kullanılarak yapılan çalışmaların büyük bir bölümünde kapsanan ülke gruplarındaki ekonomilerin gelişmişlik ve gelir düzeyi farklılıklarının dikkate alınmadan modellendiği görülmektedir. Genellikle gelişmiş/yüksek gelirli veya gelişmekte olan düşük gelirli ülke grupları için yapılan çalışmalarda kurumsal yapının ekonomik büyüme üzerindeki etkisinin, kurumsal 
yapıyı temsilen kullanılan değişkenlere ve ülke gruplarının ekonomik gelişmişlik seviyesine göre önemli ölçüde farklılaştğı da yine ilgili literatürden izlenmektedir. Bu bağlamda, yüksek gelirli ve/veya gelişmiş ülkelerde kurumların ve kurumsal yapı göstergelerinin ekonomik büyüme üzerindeki etkilerinin genellikle pozitif yönlü ve anlamlı olduğu görülmektedir. Ancak, düşük-orta gelirli ve az gelişmiş/gelişmekte olan ülkelerde kurumların ve kurumsal yapı göstergelerinin ekonomik büyüme üzerindeki etkileri için aynı genel değerlendirmeleri yapmak mümkün olmamaktadır. Nitekim söz konusu ülkelerde kurumsal yapının kötü ve zayıf bir nitelikte olması, kurumsal düzenlemelerin etkin olmaması, resmi-gayri resmi kurumsal düzenlemelerin birbirleriyle uyumlu olmaması vb. nedenlerle kurumların ve kurumsal yapı göstergelerinin ekonomik büyüme üzerindeki etkilerinin daha çok negatif yönlü veya anlamsız olduğu belirtilmektedir. (Helliwell, 1994; Alesina ve Perotti, 1994; Alesina vd., 1996; Sachs ve Warner, 1997; Chong ve Calderon, 2000; Chang, 2003; Yapraklı, 2008).

Bu çalışmada ise ilgili literatür taramasının ardından, kurumları ve kurumsal yapıyı temsilen en fazla kullanıldığı tespit edilen değişkenlerin, ekonomik büyüme üzerindeki etkilerinin ekonomik açıdan farkı gelişmişlik düzeyindeki ülkelerden oluşan G-20 grubu üzerinde incelenmesi amaçlanmaktadır. Böylelikle çalışmanın bulgularının hem kullanılan geniş kapsamdaki kurumsal yapı göstergeleri itibariyle hem de seçilen ülke grubu açısından bu konudaki literatüre katkı sağlayacağı düşünülmektedir.

\section{Araştırmanın Kapsamı ve Verileri}

Çalışmanın bu bölümlerinde, ekonomik açıdan farklı gelişmişlik düzeyine sahip ülkelerden oluşan G20 grubunda kurumsal yapının ekonomik büyüme üzerindeki etkileri 1996-2014 dönemi için yıllık bazda ve ekonometrik olarak incelenmektedir. ${ }^{1}$ Bununla birlikte çalışmada, kurumsal yapının ekonomik büyüme üzerindeki etkilerinin daha tutarlı bir şekilde incelenebilmesi ve sonuçlar özelinden karşılaştırma yapılabilmesi için G-20 ülkeleri ekonomik açıdan gelişmiş G-9 ve gelişmekte olan G-10 ülkeleri olarak iki alt grupta analize dâhil edilmişlerdir. ${ }^{2}$ Bu yönüyle çalışmada, G-9 ve G-10 gruplarında yer alan ülkelerin uzun vadeli ekonomik büyüme performanslarının ve ekonomik açıdan gelişmişlik seviyelerinin farklılaşmasında kurumsal yapının etkilerinin değerlendirilmesi amaçlanmıştır. Çalışmada kurumsal yapıyı temsil eden farklı nitelikteki kurumsal değişkenlerin, kişi başına düşen Reel Gayri Safi Yurtiçi Hâsıla (ekonomik büyüme) değişkeni üzerindeki etkilerini incelemek üzere tahmin edilecek modellerde kullanılan değişkenler ve kaynakları Tablo 1'de sunulmuştur.

Tablo 1. Modelde Kullanılan Değişkenler ve Kaynakları

\begin{tabular}{|c|c|c|}
\hline \multicolumn{3}{|c|}{ İnceleme Dönemi: 1996-2014 } \\
\hline Değişkenler & Tanımı & Veri Kaynağı \\
\hline PCGDP & Kişi Başına Düşen Reel GSYiH 2005 (USD) & \multirow{2}{*}{$\begin{array}{c}\text { World Bank (WB) } \\
\text { (World Development Indicators). }\end{array}$} \\
\hline GFCF & Reel Sabit Sermaye Yatırımları 2005 (USD) & \\
\hline EL & İstihdam Edilen İşgücü & $\begin{array}{c}\text { The Conference Board } \\
\text { (Total Economy Database May 2015). }\end{array}$ \\
\hline CC & Yolsuzluğun Önlenmesi Endeksi & \multirow{6}{*}{$\begin{array}{c}\text { World Bank (WB) } \\
\text { (Worldwide Governance Indicators). }\end{array}$} \\
\hline GE & Yönetimin Etkinliği Endeksi & \\
\hline PSA & Politik İstikrar ve Şiddetin Yokluğu Endeksi & \\
\hline $\mathbf{R L}$ & Düzenlemelerin Kalitesi Endeksi & \\
\hline $\mathbf{R Q}$ & Hukukun Üstünlüğü Endeksi Endeksi & \\
\hline VA & İfade Özgürlüğü ve Hesap Verebilirlik Endeksi & \\
\hline GTE & Toplam Kamu Harcamaları (USD) & $\begin{array}{l}\text { International Monetary Fund } \\
\text { (IMF-WEO). }\end{array}$ \\
\hline HF & Ekonomik Özgürlükler Endeksi & Heritage Foundation \\
\hline Not: & \multicolumn{2}{|c|}{$\begin{array}{l}\text { Modellerde kullanılan bütün değişkenler ilgili dönem aralığındaki logaritmik değerleriyle analizde } \\
\text { kullanılmışlardır. Çalışmanın ilerleyen bölümlerinde değişkenlerin önünde bulunan (LN) sembolü bu durumu } \\
\text { belirtmektedir. }\end{array}$} \\
\hline
\end{tabular}




\section{Araştırmanın Metodolojisi ve Bulguları}

Çalışmada, kurumsal yapının ekonomik büyüme üzerindeki etkileri farklı ülkelerin zaman serisi verilerinin kullanılmasından ötürü panel veri analizi ile incelenmiş ve değişkenler arasındaki uzun dönemli ilişkilerin yönünün/büyüklüğünün belirlenmesi amaçlanmıştır. Bununla birlikte, çalışmada G-9 ve G-10 gruplarında kurumsal yapının ekonomik büyüme üzerindeki etkileri farklı nitelikteki kurumsal yapı değişkenleriyle inceleneceğinden, tahmin edilecek modellerde çoklu doğrusal bağlantı sorunuyla karşılaşmamak için alternatif modellerin kurulması yoluna gidilmiştir. Çalışmada, G-9 ve G-10 gruplarında kurumsal yapı değişkenlerinin, ekonomik büyüme üzerindeki uzun dönemli etkilerini incelemek üzere sabit sermaye yatırımları ve istihdam edilen işgücü kontrol değişkenleriyle birlikte logaritmik formlarda tahmin edilecek ekonometrik modeller aşağıdaki eşitliklerde gösterilmektedir ${ }^{4}$ :

$$
\begin{aligned}
& \text { Model-1: } L N P C G D P_{i t}=\alpha_{i t}+\beta_{1} L N G F C F_{i t}+\beta_{2} L N E L_{i t}+\beta_{3} L N C C_{i t}+u_{i t} \\
& \text { Model-2: } L N P C G D P_{i t}=\alpha_{i t}+\beta_{1} L N G F C F_{i t}+\beta_{2} L N E L_{i t}+\beta_{3} L N G E_{i t}+u_{i t} \\
& \text { Model-3: } L N P C G D P_{i t}=\alpha_{i t}+\beta_{1} L N G F C F_{i t}+\beta_{2} L N E L_{i t}+\beta_{3} L N G T E_{i t}+u_{i t} \\
& \text { Model-4: } L N P C G D P_{i t}=\alpha_{\mathrm{it}}+\beta_{1} L N G F C F_{i t}+\beta_{2} L N E L_{i t}+\beta_{3} L N H F_{i t}+u_{i t} \\
& \text { Model-5: } L N P C G D P_{i t}=\alpha_{\mathrm{it}}+\beta_{1} L N G F C F_{i t}+\beta_{2} L N E L_{i t}+\beta_{3} L N P S A_{i t}+u_{i t} \\
& \text { Model-6: } L N P C G D P_{i t}=\alpha_{\mathrm{it}}+\beta_{1} L N G F C F_{i t}+\beta_{2} L N E L_{i t}+\beta_{3} L N R L_{i t}+u_{i t} \\
& \text { Model-7: } L N P C G D P_{i t}=\alpha_{i t}+\beta_{1} L N G F C F_{i t}+\beta_{2} L N E L_{i t}+\beta_{3} L N R Q_{i t}+u_{i t} \\
& \text { Model-8: } L N P C G D P_{i t}=\alpha_{i t}+\beta_{1} L N G F C F_{i t}+\beta_{2} L N E L_{i t}+\beta_{3} L N V A_{i t}+u_{i t}
\end{aligned}
$$

Çalışmada G-9 ve G-10 gruplarında kurumsal yapının ekonomik büyüme üzerindeki uzun dönemli etkilerini tespit etmek üzere yukarıda tanımlanan modeller yeni nesil panel veri analizi metodolojisi kapsamında başlıca dört aşamada araştırımaktadır. Illk aşamada, modellerde kullanılan değişkenlerde ve eşbütünleşme denklemlerinde paneli oluşturan yatay kesitler arasındaki bağımlılık (YKB) LM (Lagrange Multiplier) testleriyle incelenmektedir. Tanımlanan modellerde kullanılan değişkenlerde ve eş-bütünleşme denklemlerinde YKB'nin varlığı tespit edildikten sonra ikinci aşamada serilerin durağanlığı, yatay kesit bağımlılı̆ını göz önünde bulunduran Pesaran (2007) CADF ikinci nesil panel birim kök testleriyle araştırılmaktadır. Modellerde kullanılan tüm değişkenlerin aynı mertebeden [ı(1)] durağan olduklarının belirlenmesinin ardından üçüncü aşamada değişkenler arasında olması muhtemel uzun dönemli ilişkiler Westerlund Panel Eş-Bütünleşme testleriyle incelenmektedir. Dördüncü ve son aşamada, tanımlanan modeller için panel eş-bütünleşme testleriyle saptanan uzun dönemli eş-bütünleşme ilişkisinin katsayıları Mark vd. (2005) DSUR tahmincisiyle tahmin edilmektedir.

\subsection{Yatay Kesit Bağımsızlığı Test Sonuçları ve Değerlendirilmesi}

Panel verilerde zaman serisi verilerinde olduğu gibi serilerin durağan olması önem taşımakta, durağan olmayan seriler ile analiz yapıldığında sahte regresyon olgusu ile karşılaşılabilmekte, diğer bir deyişle sapmalı $t$, $F$ testleri ve $R^{2}$ değerleri elde edilebilmektedir. Bu nedenle, panel veri çalışmalarında güvenilir sonuçlar elde edebilmek için öncelikle serilerin durağan olup olmadıklarının test edilmesi gerekmektedir (Tatoğlu, 2013:199). Panel verilerin durağanlığını tespit etmek için kullanılacak birim kök testleri de paneli oluşturan birimlerde yatay kesit bağımlıı̆ının olup olmamasına göre birinci nesil ve ikinci nesil panel birim kök testleri 
olarak ikiye ayrılmaktadır. Birinci nesil panel birim kök testlerinde seriyi oluşturan yatay kesitlerin birbirinden bağımsız olduğu ve seriyi oluşturan birimlerden birinde meydana gelen şoktan bütün birimlerin aynı oranda etkilendikleri varsayılmaktadır. Seriyi oluşturan yatay kesitlerin birbirine bağımlı olduğu varsayımına dayanan ikinci nesil panel birim kök testlerine göre ise paneli oluşturan birimlerden birinde meydana gelen şoktan her birim farklı şekilde etkilenmektedir. Bu yönüyle paneli oluşturan birimler arasında yatay kesit bağımlılığının olması durumunda birinci nesil panel birim kök testleri (Hadri 2000; Levin vd., 2002; Im vd., 2003; Breitung $2005 \mathrm{vb}$.) güvenilir sonuçlar vermemektedir. Böyle bir durumda paneli oluşturan birimler arasında yatay kesit bağımlılığına izin veren (Taylor ve Sarno 1998; Breuer vd., 2002; Pesaran 2007; Hadri ve Kurozumi, 2012 vb.) ikinci nesil Panel Birim Kök Testleri kullanılabilmektedir. Bu çerçevede, panel veri çalışmalarında analize başlamadan önce serilerde ve eş-bütünleşme denkleminde yatay kesit bağımlılı̆ı̆ın araştıılması ve kullanılması gereken birim kök, eş-bütünleşme ve diğer testlerin belirlenmesi gerekmektedir. Aksi halde yapılan analizler sapmalı olabilmekte ve hatalı sonuçlar verebilmektedir.

Diğer yandan, panel verilerde yatay kesit bağımsızığını tespit edebilmek için serinin zaman ve yatay kesit boyutunun göz önüne alınması gerekmektedir. Panelin zaman boyutu yatay kesit boyutundan büyük olduğunda (T>N) Breusch ve Pagan (1980) CD-LM1 testi; zaman boyutunun yatay kesit boyutundan küçük olduğu $(T<N)$ veya zaman boyutunun yatay kesit boyutuna eşit olduğu $(T=N)$ durumlarda ise Pesaran (2004) CD-LM2 testi kullanılabilmektedir. Ancak, Breusch ve Pagan (1980) CD-LM1 ve Pesaran (2004) CD-LM2 testleri grup ortalamasının sıfir fakat birim ortalamasının sıfirdan farklı olduğu durumlarda sapmalı sonuçlar vermektedir. Bu nedenle, gurup ortalamasının sıfir ancak birim ortalamasının sıfirdan farklı olduğu durumlarda iyi sonuçlar vermeyen CD-LM1 ve CDLM2 testleri Pesaran ve diğerleri tarafindan 2008 yılında yapılan çalışmada aşağıdaki gibi geliştirilmiştir.

$$
L M_{a d j}=N L M^{* *}=\sqrt{\frac{2 T}{N(N-1)}}\left(\sum_{i=j}^{n-1} \sum_{j=i+1}^{n} \frac{(T-K) \breve{\rho}_{i j}^{2}-\mu_{T i j}}{u_{T i j}}\right)
$$

Pesaran vd., (2008) yapmış oldukları çalışmalarında, test istatistiğine birimlerin ortalamasını $\left(\mu_{\text {Tij }}\right)$ ve varyansını $\left(U_{T i j}\right)$ dâhil ederek elde ettikleri yeni istatistiğinin; bireysel ortalamanın sıfirdan farklı olduğu durumlarda CD-LM1 ve CD-LM2 testlerinden daha tutarlı sonuçlar verdiğini belirtmişlerdir (Pesaran vd., 2008:105-127). Düzeltilmiş CD-LM testi olarak (CD-LMadj) ifade edilen teste, temel hipotez "değişken veya modelde yatay kesit bağımlııı̆ı yoktur" şeklinde tanımlanmaktadır. Asimtotik olarak standart normal dağılım özelliğine sahip olduğu varsayılan testte temel hipotezin reddedilmesi durumunda modelde veya seride yatay kesit bağımlılığının olduğu sonucuna varılmaktadır. Çalışmada, G-9 ve G-10 grupları için tanımlanan modellerdeki değişkenlerde ve eş-bütünleşme denklemlerinde yatay kesit bağımlılı̆̆ının varlığı CD-LM adj testi ile incelenmiş ve sonuçları Tablo 2'de sunulmuştur.

Tablo 2'deki CD-LMadj test sonuçları G-9 ve G--10 grupları açısından incelendiğinde; tanımlanan modellerde kullanılan bütün değişkenler ve eş-bütünleşme denklemlerine ait olasılık değerlerinin 0.01 'den küçük olduğu görülmektedir. Bu nedenle, iki ülke grubunda değişkenler ve eş-bütünleşme denklemleri için CD-LMadj testlerine göre kurulan temel hipotezlerin (birimler arasında yatay kesit bağımlılı̆̆ı yoktur) güçlü bir biçimde reddedilmesi ve alternatif hipotezlerin kabul edilmesi gerekmektedir. Bu sonuçlar, her iki ülke grubunda paneli oluşturan yatay kesit birimler arasında tanımlı modellerde yer alan değişkenler ve eşbütünleşme denklemleri açısından yatay kesit bağımlılı̆ının bulunduğunu ortaya koymaktadır.

Tablo 2. Yatay Kesit Bağımsızlığı Test Sonuçları 
O. Yalcinkaya - S. Yazgan

\begin{tabular}{|c|c|c|c|c|c|c|}
\hline & \multicolumn{3}{|c|}{ G-9 } & \multicolumn{3}{|c|}{ G-10 } \\
\hline Değişkenler & CD-LMadj İst. & $\mathbf{L}$ & $\mathbf{T}$ & CD-LMadj İst. & $\mathbf{L}$ & $\mathbf{T}$ \\
\hline LNPCGDP & $27.83 *[0.000]$ & 4 & 1 & $48.59 *[0.000]$ & 3 & 0 \\
\hline LNGFCF & $42.07 *[0.000]$ & 2 & 1 & $47.39 *[0.000]$ & 2 & 1 \\
\hline LNEL & $34.20 *[0.000]$ & 2 & 1 & $26.40 *[0.000]$ & 3 & 1 \\
\hline LNCC & $36.86 *[0.000]$ & 3 & 0 & $40.05 *[0.000]$ & 3 & 1 \\
\hline LNGE & $44.77 *[0.000]$ & 4 & 1 & $51.13 *[0.000]$ & 2 & 1 \\
\hline LNGTE & $36.70 *[0.000]$ & 4 & 0 & $54.67 *[0.000]$ & 2 & 0 \\
\hline LNHF & $33.44 *[0.000]$ & 3 & 1 & $36.49 *[0.000]$ & 3 & 0 \\
\hline LNPSA & $39.85 *[0.000]$ & 3 & 0 & $68.41 *[0.000]$ & 2 & 0 \\
\hline LNRL & $61.19 *[0.000]$ & 2 & 0 & $32.06 *[0.000]$ & 4 & 0 \\
\hline LNRQ & $45.35 *[0.000]$ & 2 & 1 & $38.09 *[0.000]$ & 3 & 1 \\
\hline LNVA & $33.71 *[0.000]$ & 3 & 1 & $37.71 *[0.000]$ & 3 & 1 \\
\hline Model-1 & $5.47 *[0.000]$ & \multirow{7}{*}{3} & \multirow{7}{*}{1} & $4.59 *[0.000]$ & \multirow{7}{*}{3} & \multirow{7}{*}{1} \\
\hline Model-2 & $6.78[0.000]$ & & & $6.49 *[0.000]$ & & \\
\hline Model-3 & $5.08 *[0.000]$ & & & $6.08 *[0.000]$ & & \\
\hline Model-4 & $5.95 *[0.000]$ & & & $5.87 *[0.000]$ & & \\
\hline Model-5 & $7.29 *[0.000]$ & & & $9.35 *[0.000]$ & & \\
\hline Model-6 & $5.91 *[0.000]$ & & & $5.88 *[0.000]$ & & \\
\hline Model-7 & $3.65 *[0.000]$ & & & $4.98 *[0.000]$ & & \\
\hline Model-8 & $5.33 *[0.000]$ & & & $6.76 *[0.000]$ & & \\
\hline
\end{tabular}

Not: CD-LMadj test istatistiklerinin önünde yer alan $\left(^{*}\right)$ işareti ilgili değişkenlerde ve tanımlı modellerdeki eş-bütünleşme denklemlerinde \% 1 anlamlıık düzeyine göre yatay kesit bağımlılığının olduğunu göstermektedir. Tablodaki "T" sütununda yer alan "1" rakamı ilgili değişken ile modelin sabitli ve trendli formda tahmin edildiğini " 0 " rakamı ise sadece sabitli formda tahmin edildiğini belirtmektedir. Tablodaki $L$ sütunu değişkenler ve eş bütünleşme denklemleri için Schwarz bilgi kriterine göre belirlenen optimal gecikme uzunluklarını ve "[ ]" parantez içindeki değerler ise CD-LM adj test istatistiklerine ait olasılık değerlerini göstermektedir.

\subsection{Panel Birim Kök Testi Sonuçları ve Değerlendirilmesi}

Tablo 2'de yer alan yatay kesit bağımlılı̆ı test sonuçları analizin ilerleyen aşamalarında YKB'yi dikkate alan yeni nesil panel veri test yöntemlerinin kullanılması gerektiğine işaret etmektedir. Bu çalışmada, G-9 ve G-10 gruplarında tanımlı modellerdeki değişkenlerin durağanlık durumu, Pesaran (2007) tarafindan geliştirilen ve YKB'yi dikkate alan CADF (Cross-sectional Augmented Dickey Fuller) ikinci nesil panel birim kök testiyle araştııımaktadır. $\mathrm{N}>\mathrm{T}$ ve $\mathrm{N}<\mathrm{T}$ durumlarında anlamlı sonuçlar verebilen bu teste, önce paneli oluşturan tüm birimler için CADF test istatistiği değerleri hesaplanmakta, daha sonra bu testlerin aritmetik ortalaması alınarak panel geneli için CIPS (Cross-Sectionally Augmented IPS) testi istatistiği değerleri hesaplanmaktadır. Bununla beraber, CADF testi sonuçları paneli oluşturan her bir ülke için durağanlık analizi yaparken, CIPS testi sonuçları ise panelin geneli için durağanlık analizi yapmaktadır. CADF test istatistik değerleri aşağıdaki gibi hesaplanmaktadır:

$$
t(N, T)=\frac{\Delta y_{i}^{\prime} \overline{\mathrm{M}}_{i} y_{i-1}}{\overline{\mathbf{\sigma}}^{2}\left(\Delta y_{i-1}^{\prime} \overline{\mathrm{M}}_{i} y_{i-1}\right)^{\frac{1}{2}}}
$$

Burada;

$$
\bar{M}=\left(\tau, \Delta \bar{y}, \bar{y}_{t-1}\right)
$$

Eşitlik 11'deki Tau " $\tau$ " ve diğer değerler ise aşağıdaki gibi tanımlanmaktadır

$$
\tau=(1,1, \ldots 1)^{\prime}
$$


$\Delta \bar{y}=\left(\Delta \bar{y}_{1}, \Delta \bar{y}_{2}, \ldots \Delta \bar{y}_{t}\right)^{\prime}$

$\overline{\mathrm{y}}_{t-1}=\left(\bar{y}_{0}, \bar{y}_{1}, \ldots \bar{y}_{t-1}\right)^{\prime}$

$\overline{\boldsymbol{\sigma}}^{2}=\frac{\Delta y_{i}^{\prime} \overline{\mathrm{M}}_{i, w} \Delta y_{i}}{T-4}$

Eşitlik 10'daki, CADF test istatistiği değerleri hesaplandıktan sonra CIPS istatistik değerleri de aşağıdaki gibi hesaplanmaktadır:

$$
\text { CIPS }=\mathrm{N}^{-1} \sum_{\mathrm{i}=1}^{\mathrm{n}} \mathrm{t}(\mathrm{N}, \mathrm{T})
$$

Elde edilen CADF ve CIPS test istatistiği değerleri Pesaran tarafindan Monte Carlo simülasyonları ile oluşturulan, makalesindeki kritik tablo değerleri ile karşılaştrılmakta ve durağanlık için hipotezler sınanmaktadır. Burada, hesaplanan CADF ve CIPS test istatistik değerlerinin kritik tablo değerlerinden mutlak değer olarak büyük olması durumunda temel hipotez (seride birim kök vardır) reddedilmekte ve ilgili birimpanel geneli için alternatif hipotez (seride birim kök yoktur) kabul edilmektedir (Pesaran, 2007:265-312). Çalışmada G-9 ve G-10 grupları için tanımlanan modellerde kullanılan değişkenlerin durağanlık durumu CADF testinden elde edilen CIPS Panel Birim Kök testiyle incelenmiş ve Pesaran (2007) tarafindan hesaplanan kritik tablo değerleri ile birlikte Tablo 3'te sunulmuştur.

Tablo 3. CADF Panel Birim Kök Testi Sonuçları

\begin{tabular}{|c|c|c|c|c|c|c|c|c|}
\hline & \multicolumn{4}{|c|}{ G-9 } & \multicolumn{4}{|c|}{ G-10 } \\
\hline Değişkenler & Seviye & 1. Fark & $\mathbf{L}$ & $\mathbf{T}$ & Seviye & 1. Fark & $\mathbf{L}$ & $\mathbf{T}$ \\
\hline LNPCGDP & -1.34 & $-3.77 *$ & 4 & 1 & -2.31 & $-3.98 *$ & 3 & 0 \\
\hline LNGFCF & -2.86 & $-3.54 *$ & 2 & 1 & -2.70 & $-3.81^{*}$ & 2 & 1 \\
\hline LNEL & -1.20 & $-2.85^{*}$ & 2 & 0 & -1.30 & $-3.13 * *$ & 3 & 1 \\
\hline LNCC & -0.56 & $-4.46^{*}$ & 3 & 0 & -1.34 & $-4.21 *$ & 3 & 1 \\
\hline LNGE & -1.61 & $-3.39 *$ & 2 & 0 & -2.56 & $-3.28 *$ & 2 & 1 \\
\hline LNGTE & -1.82 & $-3.78 *$ & 4 & 0 & -1.77 & $-2.61^{*}$ & 2 & 0 \\
\hline LNHF & -2.83 & $-3.47^{*}$ & 3 & 1 & -1.80 & $-3.37 *$ & 3 & 0 \\
\hline LNPSA & -2.16 & $-2.79 *$ & 3 & 0 & -2.09 & $2.63 *$ & 2 & 0 \\
\hline LNRL & -2.00 & $-2.70^{*}$ & 2 & 0 & -2.03 & $-2.74 *$ & 4 & 0 \\
\hline LNRQ & -1.93 & $-2.97 * *$ & 2 & 1 & -1.91 & $-3.84 *$ & 3 & 1 \\
\hline LNVA & -2.58 & $-4.31^{*}$ & 3 & 1 & -2.76 & $-3.06 * *$ & 3 & 1 \\
\hline \multirow{3}{*}{\multicolumn{4}{|c|}{ CIPS Kritik Tablo Değerleri }} & 0 & \multicolumn{2}{|l|}{-2.60} & \multicolumn{2}{|c|}{-2.34} \\
\hline & & & & 1 & \multicolumn{2}{|l|}{-3.15} & \multicolumn{2}{|c|}{-2.88} \\
\hline & & & & & \multicolumn{2}{|l|}{ (\% 1) } & \multicolumn{2}{|c|}{$(\% 5)$} \\
\hline
\end{tabular}

Not: CIPS istatistiklerinin önünde yer alan $\left({ }^{*}\right)$ ve $\left({ }^{* *}\right)$ işaretleri değişkenlerin sırasıyla $\% 1$ ve $\% 5$ anlamlılık düzeyinde durağan olduklarını göstermektedir. CADF ve CIPS testlerinde optimal gecikme uzunlukları Schwarz bilgi kriterine göre belirlenmiş ve CIPS istatistiği kritik tablo değerleri T ve N spesifikasyonuna uygun olarak Pesaran (2007) çalışmasından alınmıştır. Tablodaki " $T$ " ve " $L$ " sütunları hakkında Tablo 2'deki açıklamalara bakınız.

Tablo 3'teki sonuçlar incelendiğinde, her iki ülke grubunda bütün değişkenlerin \% 5 anlamlılık düzeyine göre seviye düzeyinde [I(0)] durağan olmadıkları görülmektedir. Bu durum, değişkenler için sabitli veya sabitli ve trendli formlarda hesaplanan CIPS istatistik değerlerinin kritik tablo değerlerinden 0.05 önem düzeyinde mutlak değer olarak küçük olmasından anlaşılmaktadır. Bu nedenle, her iki ülke grubunda da serilerin birinci farklarının alınması yoluna gidilmiş ve değişkenlerin birinci farkları alındığında [ı(1)] tüm değişkenlerin \% 1 veya \% 5 önem düzeyine göre durağanlaştı̆̆ tespit edilmiştir. Bu durum, değişkenler için sabitli veya sabitli ve trendli formlarda hesaplanan CIPS istatistik değerlerinin kritik tablo değerlerinden 0.01 veya 0.05 önem düzeyinde mutlak değer olarak büyük olmasından anlaşılmaktadır. Bu sonuçlar, G-9 ve G-10 
gruplarında tanımlı modellerde kullanılan bütün değişkenlerin seviye düzeyinde durağan olmadıklarını, ancak birinci farkları alındığında durağanlaştiklarını ortaya koymaktadır.

\subsection{Panel Eş-Bütünleşme Testi Sonuçları ve Değerlendirilmesi}

Seviye düzeyinde durağan olmayan, ancak farkları alınarak durağanlaştırılan serilerde, bu fark alma işlemi serilerinin geçmiş süreçte maruz kaldığı geçici şokların etkisini yok ettiği gibi aynı zamanda bu seriler arasında olması muhtemel uzun dönemli ilişkileri de ortadan kaldırabilmektedir. Böyle bir durumda iktisadi değişkenlere ait seriler durağan olmasalar bile bu serilerin durağan bir kombinasyonu var olabilir ve eğer varsa bu eş-bütünleşme analizi ile belirlenebilir. Bu durumdaki serilerin eş-bütünleşik olması, değişkenleri etkileyen kalıcı şoklar olması durumunda bile değişkenlerin uzun dönemde bir denge ilişkisinin olduğunu belirtir (Tarı, 2010: 415). Yatay kesit bağımlılığı olmayan modellerde (Johansen 1988; Kao 1999; Pedroni 1999 vb.) birinci nesil eş-bütünleşme testleri güvenilir sonuçlar verirken, eş-bütünleşme denkleminde yatay kesit bağımlılı̆ının olması durumunda bu testler güvenilir sonuçlar vermemektedir. Böyle bir durumda değişkenler arasında yatay kesit bağımlılığına izin veren (Westerlund ve Edgerton, 2007; Westerlund, 2008 vb.) ikinci nesil panel eş-bütünleşme testlerinin kullanılması gerekmektedir.

Bu çalışmada kullanılan Westerlund ve Edgerton (2007) Panel Eş-Bütünleşme testinde, temel hipotez değişkenler arasında eş-bütünleşme ilişkisinin bulunduğunu belirten LM test istatistiği ile araştrılmaktadır. Bu testte, LM istatistiklerine göre hesaplanan test istatistikleri 1.645 kritik tablo değerinden büyükse temel hipotez (yatay kesit seriler arasında eş-bütünleşme ilişkisi vardır) kabul edilmekte ve alternatif hipotez (yatay kesit seriler arasında eş-bütünleşme ilişkisi yoktur) reddedilmektedir (Westerlund and Edgerton, 2007: 185190). Böylelikle tanımlanan modelde yer alan değişkenler arasında uzun dönemli bir eş-bütünleşme ilişkisinin olduğuna karar verilmektedir. Çalışmada, G-9 ve G-10 grupları için tanımlı modellerde yer alan değişkenler arasındaki uzun dönemli eş-bütünleşme ilişkilerinin varlığı Westerlund-Edgerton (2007) Panel Eş-Bütünleşme testiyle incelenerek sonuçları Tablo 4'te sunulmuştur.

Tablo 4. Westerlund-Edgerton (2007) Panel Eş-Bütünleşme Test Sonuçları

\begin{tabular}{|c|c|c|c|c|c|c|c|c|}
\hline \multicolumn{10}{|c|}{ G-9 } \\
\hline LM & Model-1 & Model-2 & Model-3 & Model-4 & Model-5 & Model-6 & Model-7 & Model-8 \\
\hline $\begin{array}{c}\text { Test- } \\
\text { Istatistiği }\end{array}$ & $7.05^{*}$ & $6.40^{*}$ & $6.16^{*}$ & $6.73^{*}$ & $6.76^{*}$ & $7.29^{*}$ & $7.32^{*}$ & $6.82^{*}$ \\
{$[0.997]$} & {$[0.998]$} & {$[1.000]$} & {$[0.999]$} & {$[0.997]$} & {$[0.991]$} & {$[0.992]$} & {$[0.998]$} \\
\hline \multicolumn{10}{|c|}{ G-10 } \\
\hline LM & Model-1 & Model-2 & Model-3 & Model-4 & Model-5 & Model-6 & Model-7 & Model-8 \\
\hline Test- & $7.45^{*}$ & $8.05^{*}$ & $8.78^{*}$ & $7.00^{*}$ & $7.70^{*}$ & $* 7.69$ & $7.54^{*}$ & $8.36^{*}$ \\
istatistiği & {$[0.996]$} & {$[0.978]$} & {$[0.913]$} & {$[0.999]$} & {$[0.979]$} & {$[0.994]$} & {$[0.997]$} & {$[0.987]$} \\
\hline
\end{tabular}

Not: LM test istatistiklerinin önünde yer alan ( $\left.{ }^{*}\right)$ işareti \% 1 anlamlılık düzeyine göre ilgili modeldeki seriler arasında eş-bütünleşme ilişkisinin bulunduğu anlamına gelmektedir. Westerlund-Edgerton (2007) testleri için rapor edilen olasılık değerleri yatay kesit bağımlıı̆̆ını dikkate alan 10.000 tekrarlı bootstrap dağılımından ve test istatistikleri de sabitli ve trendli formdan elde edilmiştir. "[ ]" parantez içindeki rakamlar LM test istatistiklerine ait olasılık değerlerini göstermektedir.

Tablo 4'teki Westerlund-Edgerton test sonuçları incelendiğinde; her iki ülke grubunda bütün modellerde temel hipotezin (yatay kesit seriler arasında eş-bütünleşme ilişkisi vardır) kabul edildiği ve alternatif hipotezin \% 1 önem düzeyinde reddedildiği görülmektedir. Bu durum, tanımlanan modeller için hesaplanan LM test istatistik değerlerinin 1.645 kritik tablo değerlerinden büyük olmasından anlaşılmaktadır. Bu sonuçlar, G-9 ve G-10 gruplarında tanımlanan istisnasız bütün modellerde uzun dönemde güçlü bir eşbütünleşme ilişkisinin olduğunu ve değişkenlerin uzun dönemde benzer trendleri takip etme eğiliminde olduklarını göstermektedir.

\subsection{Panel DSUR ile Uzun Dönem Eş-Bütünleşme Katsayılarının Tahmini ve Değerlendirilmesi}


G-9 ve G-10 grupları için tanımlanan modellerde yer alan değişkenler arasındaki uzun dönemli ilişkiler eş-bütünleşme testleri ile belirlendikten sonra bağımsız değişkenlere ait uzun dönem katsayılarının nasıl tahmin edileceği sorunu ortaya çıkmaktadır. Çalışmada, G-9 ve G-10 grupları için tanımlanan modellerde yatay kesit bağımlılı̆̆ı tespit edildiğinden, modellerdeki bağımsız değişkenlerin bağımlı değişken üzerindeki uzun dönemli etkilerinin büyüklügünün YKB'yi dikkate alan tahmincilerle belirlenmesi gerekmektedir. Mark vd., (2005) tarafindan geliştirilen DSUR yöntemi, modeldeki çoklu eş-bütünleşik regresyonları parametrik bir yöntemle tahmin etmekte ve denklemler arasındaki eş-bütünleşik vektörlerin homojen veya heterojen olduğu durumlarda da kullanılabilmektedir. DSUR yöntemi, zaman boyutunun yatay kesit boyutundan büyük olduğu durumlarda daha tutarlı ve asimtotik olarak normal dağılım sağlayan sonuçlar üretebilmekle birlikte zaman boyutunun yatay kesit boyutundan küçük olduğu durumlarda kullanılabilmektedir (Mark vd., 2005: 797-820). Çalışmada G-10 ve G-9 gruplarında, kurumsal yapının ekonomik büyüme üzerindeki uzun dönemli etkilerini incelemek üzere kurulan modeller DSUR yöntemi ile tahmin edilmiş ve elde edilen sonuçlar Tablo 5 'te sunulmuştur.

Tablo 5. Uzun Dönemli Eş-Bütünleşme Katsayıları: Panel DSUR Sonuçları

\begin{tabular}{|c|c|c|c|c|c|c|}
\hline \multicolumn{7}{|c|}{ Bağımlı Değişken: LNPCGDP } \\
\hline & & G-9 & & & G-10 & \\
\hline \multirow[b]{2}{*}{$\begin{array}{l}\frac{1}{1} \\
\frac{0}{0} \\
\frac{0}{2}\end{array}$} & LNGFCF & LNEL & LNCC & LNGFCF & LNEL & LNCC \\
\hline & $\begin{array}{c}0.632 * \\
(0.056) \\
{[0.000]} \\
\end{array}$ & $\begin{array}{c}0.099 * \\
(0.016) \\
{[0.000]} \\
\end{array}$ & $\begin{array}{c}0.844 * \\
(0.101) \\
{[0.000]} \\
\end{array}$ & $\begin{array}{c}0.537 \\
(0.417) \\
{[0.200]} \\
\end{array}$ & $\begin{array}{c}1.407^{*} \\
(0.185) \\
{[0.000]} \\
\end{array}$ & $\begin{array}{c}\mathbf{2} .246 * * \\
(0.893) \\
{[0.013]} \\
\end{array}$ \\
\hline \multirow[b]{2}{*}{$\begin{array}{l}\frac{N}{1} \\
\frac{0}{0} \\
\frac{0}{\Sigma}\end{array}$} & LNGFCF & $\overline{\text { LNEL }}$ & LNGE & LNGFCF & LNEL & LNGE \\
\hline & $\begin{array}{c}0.614 * \\
(0.067) \\
{[0.000]} \\
\end{array}$ & $\begin{array}{c}0.094 * \\
(0.017) \\
{[0.000]}\end{array}$ & $\begin{array}{l}\text { 0.888* } \\
(0.125) \\
{[0.000]}\end{array}$ & $\begin{array}{l}1.704 * \\
(0.505) \\
{[0.001]}\end{array}$ & $\begin{array}{l}2.047 * \\
(0.256) \\
{[0.000]}\end{array}$ & $\begin{array}{c}-5.910 * \\
(1.323) \\
{[0.000]}\end{array}$ \\
\hline \multirow[b]{2}{*}{$\begin{array}{l}\frac{n}{1} \\
\frac{0}{0} \\
\frac{0}{\Sigma}\end{array}$} & LNGFCF & LNEL & LNGTE & LNGFCF & LNEL & LNGTE \\
\hline & $\begin{array}{c}0.543 * \\
(0.028) \\
{[0.000]}\end{array}$ & $\begin{array}{l}0.084 * \\
(0.011) \\
{[0.000]}\end{array}$ & $\begin{array}{l}\text { 0.446* } \\
(0.022) \\
{[0.000]}\end{array}$ & $\begin{array}{l}5.981 * \\
(0.460) \\
{[0.000]}\end{array}$ & $\begin{array}{l}3.924 * \\
(0.219) \\
{[0.000]}\end{array}$ & $\begin{array}{c}-7.153^{*} \\
(0.486) \\
{[0.000]}\end{array}$ \\
\hline \multirow[b]{2}{*}{$\begin{array}{l}\frac{y}{1} \\
\frac{1}{0} \\
\frac{0}{2}\end{array}$} & LNGFCF & LNEL & LNHF & LNGFCF & LNEL & LNHF \\
\hline & $\begin{array}{c}0.932 * \\
(0.076) \\
{[0.000]}\end{array}$ & $\begin{array}{c}0.089 * \\
(0.019) \\
{[0.000]}\end{array}$ & $\begin{array}{c}0.279 * * \\
(0.129) \\
{[0.044]}\end{array}$ & $\begin{array}{l}4.068 * \\
(0.516) \\
{[0.000]}\end{array}$ & $\begin{array}{l}3.007 * \\
(0.243) \\
{[0.000]}\end{array}$ & $\begin{array}{c}-12.35^{*} \\
(1.335) \\
{[0.000]}\end{array}$ \\
\hline \multirow[b]{2}{*}{$\begin{array}{l}\frac{1}{1} \\
\frac{0}{0} \\
\frac{0}{\Sigma}\end{array}$} & LNGFCF & LNEL & LNPSA & LNGFCF & LNEL & LNPSA \\
\hline & $\begin{array}{c}0.913 * \\
(0.045) \\
{[0.000]}\end{array}$ & $\begin{array}{l}0.105 * \\
(0.019) \\
{[0.000]}\end{array}$ & $\begin{array}{l}0.282 * \\
(0.071) \\
{[0.000]}\end{array}$ & $\begin{array}{c}1.118 * * \\
(0.431) \\
{[0.010]}\end{array}$ & $\begin{array}{l}1.261 * \\
(0.169) \\
{[0.000]}\end{array}$ & $\begin{array}{c}1.361 \\
(0.857) \\
{[0.098]}\end{array}$ \\
\hline \multirow[b]{2}{*}{$\begin{array}{l}\frac{0}{1} \\
\frac{1}{0} \\
\frac{0}{2}\end{array}$} & LNGFCF & LNEL & LNRL & LNGFCF & LNEL & LNRL \\
\hline & $\begin{array}{c}0.707 * \\
(0.063) \\
{[0.000]} \\
\end{array}$ & $\begin{array}{c}0.093 * \\
(0.018) \\
{[0.000]}\end{array}$ & $\begin{array}{c}0.704 * \\
(0.117) \\
{[0.000]}\end{array}$ & $\begin{array}{c}0.977 * * \\
(0.403) \\
{[0.016]}\end{array}$ & $\begin{array}{l}1.651 * \\
(0.204) \\
{[0.000]}\end{array}$ & $\begin{array}{c}-3.811 * \\
(0.975) \\
{[0.000]}\end{array}$ \\
\hline \multirow{2}{*}{$\begin{array}{l}\frac{1}{0} \\
\frac{1}{0} \\
\frac{0}{\Sigma}\end{array}$} & LNGFCF & LNEL & LNRQ & LNGFCF & LNEL & LNRQ \\
\hline & $\begin{array}{l}0.423 * \\
(0.053) \\
{[0.000]} \\
\end{array}$ & $\begin{array}{c}\text { 0.111* } \\
(0.014) \\
{[0.000]} \\
\end{array}$ & $\begin{array}{l}1.233^{*} \\
(0.097) \\
{[0.000]} \\
\end{array}$ & $\begin{array}{l}1.694^{*} \\
(0.465) \\
{[0.000]} \\
\end{array}$ & $\begin{array}{l}1.799 * \\
(0.203) \\
{[0.000]} \\
\end{array}$ & $\begin{array}{c}-5.348^{*} \\
(1.080) \\
{[0.000]} \\
\end{array}$ \\
\hline \multirow[b]{2}{*}{$\begin{array}{l}\frac{\infty}{1} \\
\frac{1}{0} \\
\frac{0}{\Sigma}\end{array}$} & LNGFCF & LNEL & LNVA & LNGFCF & LNEL & LNVA \\
\hline & $\begin{array}{c}0.317 * \\
(0.043) \\
{[0.000]}\end{array}$ & $\begin{array}{l}0.139 * \\
(0.012) \\
{[0.000]}\end{array}$ & $\begin{array}{l}1.381 * \\
(0.075) \\
{[0.000]}\end{array}$ & $\begin{array}{c}0.406 * * \\
(0.187) \\
{[0.031]}\end{array}$ & $\begin{array}{l}1.965 * \\
(0.127) \\
{[0.000]}\end{array}$ & $\begin{array}{c}-3.969 * \\
(0.280) \\
{[0.000]}\end{array}$ \\
\hline
\end{tabular}

Not: Modellerde değişkenler için hesaplanan katsayıların önünde bulunan $\left({ }^{*}\right)$ ve $\left({ }^{* *}\right)$ işaretleri katsayılara ait t-istatistiklerinin sırasıyla \% 1 ve \% 5 önem düzeyine göre anlamlı olduğunu göstermektedir. "( )" parantez içindeki değerler katsayılara ait standart hataları ve "[ ]" köşeli parantez içindeki değerler ise katsayılara ait olasılık değerlerini göstermektedir. 
Tablo 5'teki sonuçlar; ABD, Almanya, Avustralya, Fransa, Güney Kore, İngiltere, İtalya, Japonya ve Kanada ekonomilerinden oluşan G-9 grubu açısından incelendiğinde, beklentilerle uyumlu olarak GFCF, EL, $\mathrm{CC}, \mathrm{GE}, \mathrm{GTE}, \mathrm{HF}, \mathrm{PSA}, \mathrm{RL}, \mathrm{RQ}$ ve VA açıklayıcı değişkenlerinin katsayılarının istisnasız bütün modellerde pozitif ve istatistiki olarak farklı önem düzeylerinde anlamlı olduğu sonucuna ulaşılmıştır. Bu sonuçlar çalışma döneminde, gelişmiş ülke ekonomilerinden oluşan G-9 grubunda fiziksel sermaye birikiminde ve eğitim seviyesi veri alındığında beşeri sermaye birikiminde meydana gelen artışların/iyileşmelerin ekonomik büyümeyi pozitif ve istatistiki açıdan anlamlı bir şekilde etkilediğini ortaya koymaktadır. Sonuçlar, çalışmada kurumsal yapıyı temsilen kullanılan göstergeler açısından değerlendirildiğinde, G-9 grubunda yer alan ülke ekonomilerindeki mevcut kurumsal yapı düzeyinin, bu ülkelerde ekonomik büyümeyi pozitif yönde etkileyebilecek bir niteliğe sahip olduğunu göstermektedir.

Bununla birlikte, Tablo 5'teki sonuçlar G-9 grubunda tanımlı bütün modeller açısından ayrı ayrı incelendiğinde, fiziksel sermaye, eğitim durumundan bağımsız olarak beşeri sermaye ve kurumsal yapı göstergelerinin ekonomik büyüme üzerindeki uzun dönemli ve pozitif yönlü etkilerinin büyüklüğünün önemli derecede farklılaştı̆ı izlenmektedir. Nitekim bütün modellerde fiziksel sermaye ve/veya kurumsal yapı göstergelerinin ekonomik büyüme üzerindeki uzun dönemli etkilerinin büyüklüğünün istihdam edilen işgücüne kıyasla çok daha fazla olduğu görülmektedir. Bu sonuçlar, inceleme döneminde G-9 grubunda bir yandan fiziksel-beşeri sermaye ve kurumsal yapı göstergelerinin ekonomik büyüme üzerindeki etkilerinin pozitif yönlü olduğunu göstermekte, diğer yandan da G-9 grubu ülkelerinin ekonomik büyüme performanslarının diğer şartlar sabitken daha çok fiziksel sermaye birikiminden ve kurumsal yapıdan kaynaklandığını ortaya koymaktadır.

Tablo 5'teki sonuçlar; Arjantin, Brezilya, Çin Halk Cumhuriyeti, Endonezya, Güney Afrika, Hindistan, Meksika, Rusya, Suudi Arabistan ve Türkiye ekonomilerinden oluşan G-10 grubu açısından incelendiğinde, beklentilerle uyumlu olarak GFCF ve EL açıklayıcı değişkenlerinin katsayılarının bütün modellerde pozitif ve istatistiki olarak farklı önem düzeylerinde anlamlı olduğu (Model-1'de GFCF değişkeni hariç) belirlenmiştir. Buna karşılık, tanımlı modellerde kurumsal yapıyı temsil eden farklı nitelikteki CC, GE, GTE, HF, RL, RQ ve VA açıklayıcı değişkenlerinin katsayılarının ise negatif (Model-5'te PSA değişkeni hariç) ve istatistiki olarak farklı önem düzeylerinde anlamlı olduğu tespit edilmiştir. Bu sonuçlar çalışma döneminde, gelişmekte olan ülke ekonomilerinden oluşan G-10 grubunda fiziksel sermaye birikiminde ve eğitim seviyesi veri alındığında beşeri sermaye birikiminde meydana gelen artş̧arın/iyileşmelerin ekonomik büyümeyi pozitif ve istatistiki açıdan genellikle anlamlı bir şekilde etkilediğini ortaya koymaktadır. Ancak sonuçlar, kurumsal yapıyı temsilen kullanılan göstergeler açısından değerlendirildiğinde, G-10 grubunda yer alan ülke ekonomilerindeki mevcut kurumsal yapı düzeyinin, bu ülkelerde ekonomik büyümeyi pozitif yönde etkileyebilecek bir niteliğe sahip olmadığını (PSA değişkeni dışında) göstermektedir. Bu durum, inceleme döneminde G-10 grubunda bir yandan fiziksel-beşeri sermaye birikiminin ekonomik büyüme üzerindeki etkilerinin pozitif yönlü olduğunu göstermekte, diğer yandan da G-9 grubundaki ülkelerin ekonomik büyüme performanslarının diğer şartlar sabitken kurumsal yapıdan ziyade daha çok fiziksel-beşeri sermaye birikiminden kaynaklandığını ortaya koymaktadır.

Gelişmiş G-9 ve gelişmekte olan G-10 ülke gruplarında kurumsal yapının ekonomik büyüme üzerindeki etkilerini incelemek üzere kurulan Tablo 5 'teki model bulguları bir bütün olarak değerlendirildiğinde teorik ve ampirik literatürle uyumlu olduğu belirlenen sonuçları şu şekilde özetlemek mümkün olmaktadır. G-9 ve G-10 grupları için tanımlı bütün modellerde fiziksel sermaye birikimi (GFCF) ve eğitim seviyesinden bağımsız olarak beşeri sermaye birikimi (EL) değişkenlerinin ekonomik büyüme üzerindeki etkilerinin pozitif yönlü ve genellikle istatistiki açıdan anlamlı olduğu tespit edilmiştir. Bununla birlikte, fiziksel sermaye ve beşeri sermaye değişkenlerinin ekonomik büyüme üzerindeki bu pozitif yönlü etkilerinin büyüklüğünün ise beklenildiği gibi G-10 grubunda G-9 grubuna kıyasla çok daha fazla olduğu sonucuna ulaşılmıştır.

Buna karşılık, çalışmada G-9 ve G-10 ülke gruplarında uzun dönemde ekonomik büyüme üzerindeki etkileri itibariyle farklılık yaratan asıl unsurların ise kurumsal yapı (CC, GE, GTE, HF, PSA, RL, RQ ve VA) göstergelerinin olduğu belirlenmiştir. Nitekim G-9 grubu için tanımlanan bütün modellerde kurumsal yapı göstergelerinin ekonomik büyüme üzerindeki etkilerinin pozitif yönlü ve anlamlı olduğu, ancak G-10 
grubunda ise kurumsal yapı göstergelerinin ekonomik büyüme üzerindeki etkilerinin genellikle negatif yönlü ve anlamlı olduğu tespit edilmiştir. Bu sonuçlar, G-9 grubu ülkelerindeki mevcut kurumsal düzenlemelerin ekonomik büyümeyi uyarabilecek bir niteliğe sahip olduğuna, G-10 grubu ülkelerindeki mevcut kurumsal düzenlemelerin ise bu niteliğe henüz sahip olmadığına işaret etmektedir. Özetle, çalışmada inceleme döneminde elde edilen tüm bu sonuçlar, G-9 ve G-10 grubunda yer alan ülkelerin, uzun vadeli ekonomik büyüme performanslarının diğer bir deyişle, ekonomik açıdan gelişmişlik seviyelerinin farklılaşmasında fiziksel-beşeri sermaye birikiminden ziyade farklı nitelikteki kurumsal yapılara sahip olunmasının daha fazla etkili olduğunu düşündürmektedir.

\section{Sonuç}

Kurumsal iktisat yaklaşımı ile birlikte iktisadi büyüme literatüründe ülkeler arasındaki ekonomik büyüme ve gelişmişlik/gelir düzeyi farklııkları, fiziki ve beşeri sermaye birikiminden ziyade farklı nitelikteki kurumsal yapılara sahip olunması ile açıklanmaktadır. Bu çalışmada, iktisadi büyüme teorilerinin uzun dönemli ekonomik büyümenin temel belirleyicileri konusunda geçirdiği evrimle paralel, kurumsal yapının ekonomik büyüme üzerindeki etkileri ekonomik açıdan farklı gelişmişlik düzeyine sahip G-20 ülkeleri üzerinde 1996-2014 dönemi için ekonometrik olarak incelenmektedir. Kurumsal yapının ekonomik büyüme üzerindeki etkilerinin daha tutarlı bir şekilde incelenebilmesi ve sonuçlar özelinden karşılaştırma yapılabilmesi için G-20 ülkeleri ekonomik açıdan gelişmiş G-9 ve gelişmekte olan G-10 ülkeleri olarak iki alt grupta analize dâhil edilmişlerdir. Bu yönüyle çalışmada, G-9 ve G-10 gruplarında yer alan ülkelerin uzun vadeli ekonomik büyüme performanslarının ve ekonomik açıdan gelişmişlik seviyelerinin farklılaşmasında kurumsal yapının etkilerinin değerlendirilmesi amaçlanmıştır.

Çalışmada, G-9 ve G-10 gruplarında farklı nitelikteki kurumsal yapı değişkenlerinin, ekonomik büyüme üzerindeki uzun dönemli etkilerini incelemek üzere sabit sermaye yatrımları ve istihdam edilen işgücü kontrol değişkenleriyle birlikte kurulan modeller, yatay kesit bağımlılı̆ını dikkate alan yeni nesil panel veri metodolojisi kapsamında tahmin edilmiştir. Çalışma sonucunda her iki ülke grubu üzerinde tanımlanan modellerden elde edilen teorik ve ampirik literatürle uyumlu olduğu belirlenen sonuçları şu şekilde ifade etmek mümkün olmaktadır.

G-9 ve G-10 gruplarında tanımlanan bütün modellerde (G-10 grubu Model-1'de fiziksel sermaye hariç) fiziksel ve beşeri sermaye birikimini temsilen kullanılan değişkenlerinin ekonomik büyüme üzerindeki etkilerinin pozitif yönlü ve istatistiki açıdan anlamlı olduğu tespit edilmiştir. Bununla birlikte, fiziksel ve beşeri sermaye birikimini temsilen kullanılan değişkenlerinin ekonomik büyüme üzerindeki bu pozitif yönlü etkilerinin büyüklüğünün ise beklenildiği gibi G-10 grubunda G-9 grubuna kıyasla çok daha fazla olduğu sonucuna ulaşılmıştır. Buna karşılık, G-9 ve G-10 ülke gruplarında uzun dönemde ekonomik büyüme üzerindeki etkileri itibariyle farklııık yaratan asıl unsurların ise kurumsal yapıyı temsilen kullanılan göstergeler olduğu belirlenmiştir. Nitekim G-9 grubu için tanımlanan bütün modellerde kurumsal yapı göstergelerinin ekonomik büyüme üzerindeki etkilerinin pozitif yönlü ve anlamlı olduğu, ancak G-10 grubunda ise kurumsal yapı göstergelerinin ekonomik büyüme üzerindeki etkilerinin (Model-5'te Politik İstikrar ve Şiddetin Yokluğu değişkeni hariç) negatif yönlü ve anlamlı olduğu tespit edilmiştir.

Bu durum, inceleme döneminde G-9 grubu ülkelerindeki mevcut kurumsal düzenlemelerin ekonomik büyümeyi teşvik edebilecek bir niteliğe/etkinliğe sahip olduğunu, G-10 grubu ülkelerindeki mevcut kurumsal düzenlemelerin ise bu yönde bir niteliğe/etkinliğe henüz sahip olmadığını düşündürmektedir. Bu sonuçlar çalışmada içerilen kurumsal yapı değişkenlerinin niteliği açısından değerlendirildiğinde, gelişmiş G-9 ülkelerinde kamuoyundaki toplumsal ve siyasal yöndeki kurumsal algıların; kamudaki yolsuzluk düzeyinin düşük olduğuna, siyasal-yönetimsel açıdan istikrarın ve etkinliğin sağlandığına, hukuki düzenlemelerin etkinliğine ve hukuk kurallarının üstünlüğüne olan inancın fazlalığına, ifade, medya, örgütlenme ve siyasal özgürlügünün geliştiğine, mülkiyet haklarının korunduğuna, ekonomik ve politik özgürlüklerin sağlandığına vb. ekonomik büyüme açısından olumlu yönde geliştiğine işaret etmektedir. Sonuçlar gelişmekte olan G-10 ülkelerinde ise kamuoyundaki toplumsal ve siyasal yöndeki söz konusu kurumsal algıların, (politik istikrar ve şiddet yönündeki algılar hariç) aksi ve ekonomik büyüme açısından da olumsuz yönde geliştiğine işaret etmektedir. Bu durum, G-10 grubunda yer alan gelişmekte olan ülkelerde literatürde belirtildiği gibi bir 
yandan kurumların ve kurumsal yapının kötü ve zayıf nitelikteki olduğunu göstermekte diğer yandan da kurumsal yapı düzenlemelerinin etkin olmadığını, resmi-gayri resmi kurumsal düzenlemelerin birbirleriyle uyumlu olmadığını vb. düşündürmektedir.

Tüm bunlar, inceleme döneminde iki ülke grubundaki ülkelerin, uzun vadeli ekonomik büyüme performanslarının ve ekonomik açıdan gelişmişlik seviyelerinin farklılaşmasında fiziksel ve beşeri sermaye (eğitim seviyesi veri alındığında) birikiminin yanı sıra farklı nitelikteki kurumsal yapılara sahip olunmasının daha fazla etkili olduğunu ortaya koymaktadır. Bununla birlikte sonuçlar, G-9 ve G-10 grubunda yer alan ülkelerin ekonomik açıdan gelişmişlik seviyeleri dikkate alınarak değerlendirildiğinde ise iki ülke grubu arasındaki gelişmişlik düzeyi farklııklarının önemli bir bölümünün farklı nitelikte kurumsal yapılara sahip olunması ile açıklanabileceğini göstermektedir.

Sonuç olarak, gelişmekte olan ülke ekonomilerinden oluşan G-10 grubundaki ülkelerde uzun dönemli ve sürdürülebilir büyüme performanslarının yakalanabilmesi ve böylece G-9 grubundaki ülkelerle aralarındaki gelişmişlik düzeyi farklılıklarının azaltılabilmesi için kurumsal yapı göstergeleri ile ekonomik büyüme arasındaki bağıntının güçlendirilmesi gereklilik arz etmektedir. Nitekim çalışmanın bulguları ülke ekonomilerinde sahip olunan iyi nitelikteki kurumlar ile güçlü bir kurumsal yapının daha yüksek ve uzun dönemde sürdürülebilir bir ekonomik büyüme performansının yakalanabilmesi üzerinde önemli bir rol oynadığı göstermektedir. Bu bağlamda, iki ülke grubunda yer alan ülkelerin ekonomik açıdan birbirlerine belli bir ölçüde yakınsamalarını da beraberinde getirecek olan bu süreç, elbette kurumsal yapıda uzun vadede niteliği artırıcı politikaların geliştirilip uygulanmasıyla mümkün olacaktır. Bu kapsamda, G-9 grubunu oluşturan ülke ekonomilerinde sahip olunan kurumsal yapıyı daha sağlam bir hale getirecek (iyi ve güçlü kılacak) yasal bir çerçevenin oluşturması ile birlikte kurumsal yapı göstergeleri üzerindeki kısıtların ortadan kaldırılması, bu yönde uygulanacak politikalara temel oluşturacağı düşünülmektedir. Aksi halde, çalışma döneminde iki ülke grubu arasında kurumsal yapı ve büyüme ilişkileri ile gelişmişlik düzeyi açısından mevcut olan farklılıkların yakın gelecekte de benzer olacağını şimdiden öngörmek mümkün olmaktadır. Tüm bunlara ek olarak, kurumsal yapının ekonomik büyüme üzerindeki etkilerini incelemek için yakın gelecekte yapılacak ampirik çalışmalarda, mümkün olması halinde daha geniş bir zaman aralığının ve daha fazla sayıda ülkenin kapsanmasının bu konudaki literatürün gelişimine katkı sağlayacağı düşünülmektedir.

\section{Son Notlar}

${ }^{1}$ Literatürde kurumların ve kurumsal yapının ekonomik büyüme üzerindeki etkilerini incelemek üzere yapılan çalışmaların bir bölümünde, kurumsal yapıyı temsilen kullanılan farklı nitelikteki değişkenlerin genellikle Freedom House, Transparency International, Heritage Foundation, Fraser Institute, Center For Systemic Peace, The PRS Group vb. uluslararası bağımsız sivil kuruluşlar tarafından endeks şeklinde oluşturulan veriler olduğu görülmektedir. ilgili literatürde bu kapsamdaki verilerin subjektif analizlere dayalı olarak hesaplandığı genel olarak kabul edilmekte ve bu husus yapılan çalışmaların bir bölümünde de dile getirilmektedir. Bu nedenle, çalışmada bu sakıncayı gidermek için kurumsal yapıyı temsilen kullanılan endeks şeklindeki değişkenlerin büyük bir bölümünün (nispeten daha güvenilir bir kaynak olan ve son yıllarda daha sık kullanılan) Dünya Bankası-World Bank veri tabanından temin edilebilmeleri yoluna gidilmiştir. Çalışmada inceleme döneminin 1996 yılı ile başlatılmasında, kurumsal yapıyı temsilen kullanılan değişkenlerin WB veri tabanında 1996 yılından itibaren temin edilebilmeleri etkili olmuştur.

${ }^{2}$ Çalışmada G-20 ülkeleri için böyle bir gruplandırılmaya gidilmesinde, uluslararası arenada G-9 grubunda yer alan ülkelerin gelişmiş ülke ekonomileri olarak, G-10 grubunda yer alan ülkelerin ise hızla gelişmekte olan yükselen piyasa ekonomileri olarak kabul edilmesi ve ekonomik açıdan daha homojen gruplar üzerinde çalışılması amacı da etkin olmuştur. G-9 grubunda yer alan gelişmiş ülkeler: ABD, Almanya, Avustralya, Fransa, Güney Kore, ingiltere, italya, Japonya ve Kanada, G-10 grubunda yer alan gelişmekte olan ülkeler ise: Arjantin, Brezilya, Çin Halk Cumhuriyeti, Endonezya, Güney Afrika, Hindistan, Meksika, Rusya, Suudi Arabistan ve Türkiye şeklindedir.

${ }^{3}$ GFCF değişkeni; ilgili veri tabanından reel (2005) olarak alınmış ve aynı veri tabanındaki toplam nüfusa oranlanarak kişi başına değerler cinsinden kullanılmıştır. Bununla birlikte, Suudi Arabistan için ilgili veri nominal (USD) olarak alınmış ve ülkenin GSYIH deflatörüne oranlanarak reel hale getirilmiştir. GTE değişkeni, toplam kamu harcamaların GSYiH içindeki payı olarak alınmış ve bu değişken ilgili ülkelerde kamu kesiminin ekonomideki büyüklügünü temsil ettiğinden kurumsal yapı göstergesi olarak modele dâhil edilmiştir. CC: Yolsuzluğun Önlenmesi Endeksi: kamu gücünün kişisel çıkarlar için 
kullandırılması şeklinde tanımlanan yolsuzluğa ilişkin toplumdaki algılamaları ölçmektedir. GE: Yönetimin Etkinliği Endeksi: kamu ve özel kesim hizmetlerin niteliği ve bu tür hizmetlerin siyasi baskılardan bağımsızlık derecesi, hükümet politikalarına güven gibi yönetime ilişkin algılamaları ölçmektedir. PSA: Politik Istikrar ve Şiddetin Yokluğu Endeksi: kurumsal olmayan ve/veya şiddet içeren yöntemlerle (siyasal veya terörizm) iktidardaki hükümetin dengesiz ya da işlemez duruma sokulacağı veya devrileceği ihtimaline yönelik toplumsal algılamaları ölçen çeşitli göstergeleri içermektedir. RL: Düzenlemelerin Kalitesi Endeksi: Bireylerin, suç işleme sıklı̆̆ı, adli sistemin etkinliği, sözleşmelerin uygulanabilirliğini ve mülkiyet hakları gibi toplumsal kurallara ne derece güvendiğini ve uyduğunu yansıtan göstergeleri içermektedir. RQ: Hukukun Üstünlüğü Endeksi: Hükümetin etkili politikalar ve düzenlemeler oluşturmak ve yürütmekle ilgili yeterliliğine ve özel sektör gelişimini teşvik etmeye yönelik toplumsal algılardan oluşmaktadır. VA: ifade Özgürlüğü ve Hesap Verebilirlik Endeksi: Bir ülkenin vatandaşlarının hükümetlerinin seçilmesine ne derece katılabildiklerini gösteren, siyasal özgürlükler ile birlikte, ifade özgürlüğü, örgütlenme özgürlüğü ve medya özgürlüğü gibi unsurları kapsamaktadır. Kurumsal yapıyı temsilen eden bu endekslerin içeriği ve hesaplama yöntemleri hakkında daha kapsamlı bilgi için bakınız: Kaufmann, Daniel, Kraay, Aart, Mastruzzi, Massimo, (2010). The Worldwide Governance Indicators Methodology and Analytical Issues, The World Bank Development Research Group Macroeconomics and Growth Team, Policy Research Working Paper 5430. HF: Heritage Foundation tarafından hazırlanan Ekonomik Özgürlükler Endeksi: Hukuk Kuralları (Mülkiyet Hakları, Yolsuzluk Algısı), Hükümetin Boyutu (Mali Özgürlük, Kamu Harcamaları), Düzenlemelerin Etkinliği (İ̧̧ Yapma Özgürlüğü, Işsücü Özgürlüğü, Parasal Özgürlükler) ve Piyasa Açıklığı (Ticaret Özgürlüğü, Yatırım Özgürlüğü ve Finansal Özgürlük) olmak üzere kurumsal yapıyı temsil eden dört temel başlık ve on kriter dikkate alınarak hesaplanmaktadır. Kurumsal yapıyı temsilen eden Ekonomik Özgürlükler Endeksinin hesaplanmasında kullanılan bu alt endeksler ve dikkate alınan kriterler hakkında daha kapsamlı bilgi için bakınız: Miller, Terry and Kim, Anthony, B. (2015). 2015 Index of Economic Freedom, Promoting Economic Opportunity and Prosperity, The Heritage Foundation and Dow Jones \& Company, Inc. Çalışmada WB'den alınan kurumsal yapı değişkenleri veri tabanında; 1997, 1999 ve 2001 yılları için eksik olduklarından, ilgili yıllar için bu veriler EViews 9.1 paket programında Cubic Spline metodu ile tahmin edilerek analize dâhil edilmişlerdir. Bununla birlikte, tanımlı modeller kurumsal yapı değişkenlerinin ilgili yıllardaki eksik verileriyle de tahmin edilmiş ve iki ülke grubunda benzer sonuçlarla karşılaşılmıştır.

${ }^{4}$ Çalışmada tanımlanan modellerin tahmin edilmesinde EViews 9.1, Stata 12.00 ve Gauss 10.0 paket programı ile bu program için yazılan kodlar kullanılmıştır.

\section{Kaynaklar}

Abrams, B. A., \& Lewis, K. A. (1993). Cultural and institutional determinants of economic growth: A cross-section analysis. Public Choice, 83, 273-289.

Acemoğlu, D., Johnson, S., Robinson, J., \& Thaicharoen, Y. (2003). Institutional causes, macroeconomic symptoms volatility, crises and growth. Journal of Monetary Economics, 50, 49-123.

Acemoğlu, D. (2003). Root causes: A historical approach to assessing the role of institutions in economic development. Finance and Development, 40(2), 27-30.

Akçay, S. (2002). Corruption and economic growth: Across-national study. Ankara Üniversitesi SBF Dergisi, 57(1), 1-13.

Alesina, A., \& Perotti, R. (1994). The political economy of growth: A critical survey of the recent literature. The World Bank Economic Review, 8(3), 351-71.

Alesina, A., Özler, Ş., Roubini, N., \& Swagel, P.(1996). Political instability and economic growth. Journal of Economic Growth, 1(2), 189-211.

Aron, J. (2000). Growth and institutions: A review of the evidence. The World Bank Research Observer, 15(1), 99-135.

Arslan, Ü. (2007). Kurumların iktisadi büyüme üzerindeki etkisi. Ankara Üniversitesi Sosyal Bilimler Enstitüsü (Yayımlanmamış Doktora Tezi), Ankara.

Asteriou, D., \& Price, S. (2000). Political instability and economic growth: UK time series evidence. Scottish Journal of Political Economy, 48(4), 383-399.

Bardhan, P. (1997). Corruption and development: A review of issues. Journal of Economic Literature, Vol. 35, No. 3, 1320-1346.

Barro, R. J. (1991). Economic growth in a cross section of countries. Quarterly Journal of Economics, 106 (2), $407-444$.

Barro, R. J. (2002). Quantity and quality of economic growth. Working Papers Central Bank of Chile, 168.

Berber, M. (2011). iktisadi büyüme ve kalkınma: Büyüme teorileri ve kalkınma ekonomisi (4. Baskı). Trabzon: Derya Kitapevi. 
Beşkaya, A., \& Manan, Ö. (2009). Ekonomik özgürlükler ve demokrasi ile ekonomik performans arasındaki ilişkinin zaman serileri ile analizi: Türkiye örneği. Zonguldak Karaelmas Üniversitesi Sosyal Bilimler Dergisi, 5(10), 47-76.

Beugelsdijk, S., \& Schaik, T. (2003). Social capital and regional economic growth. Center For Economic Research, Discussion Paper, 102.

Breitung, J. (2005). A parametric approach to the estimation of cointegration vectors in panel data. Econometric Reviews, 24(2), 151-173.

Breuer, J. B., Mcnown, R., \& Wallace, M. (2002). Series-specific Unit Root tests with panel data. Oxford Bulletin of Economics and Statistics, 64(5), 527-546.

Chang, H.J. (2003). Kalkınma reçetelerinin gerçek yüzü. Ankara: Iletişim Yayınları.

Chong, A., \& Calderon, C. (2000). Causality and feedback between Institutional measures and economic growth. Economics and Politics, 12(1), 69-82.

Dawson, J. F. (2003). Causality in the freedom-growth relationship. European Journal of Political Economy, Vol. 19, No. 3, 479-495.

Demir, Ö. (1996). Kurumcu iktisat (1. Basım). Ankara: Vadi Yayınları.

Devereux, M. B., \& Wen, J. (1998). Political instability, capital taxation and growth. European Economic Review, 42, 16351651.

Easton, S.T., \& Walker, M.A. (1997). Income, growth, and economic freedom. American Economic Review, 328-32.

Gregorian, D. A., \& Martinez, A. (2000). Industrial growth and the quality of Institutions. Policy Research Working Paper, 2475.

Gökalp, M. F., \& Ercan Baldemir.(2006). Kurumsal yapı ve ekonomik büyüme ilişkisi. Dokuz Eylül Üniversitesi Sosyal Bilimler Enstitüsü Dergisi, 8(1), 212-226.

Hadri, K. (2000), Testing for stationarity in heterogeneous panels. Econometrics Journal, 3, 148-161.

Hadri, K., \& Kurozumi, E., (2012). A Simple panel stationarity test in the presence of serial correlation and a common factor. Economics Letters, 115, 31-34.

Hall, R. E., \& Jones, C. I. (1999) .Why do some countries produce so much more output per worker than others?. The Quarterly Journal of Economics, Vol. 114, No. 1, 83-116.

Hayaloğlu, P. (2012). Iktisadi Büyüme Sürecinde Kurumsal Yapının Rolü: Literatür ve Uygulama. Karadeniz Teknik Üniversitesi/Sosyal Bilimler Enstitüsü (Yayımlanmamış Doktora Tezi), Trabzon.

Helliwell, J.F. (1994). Empirical linkages between democracy and economic growth. British Journal of Political Science, 24(2), 225-48.

Im, K. S., Pesaran, M. H., \& Shin, Y. (2003). Testing for unit roots in heterogeneous panels. Journal of Econometrics, 115(1), 53-74.

Johansen, S. (1988). Statistical analysis of cointegration vectors. Journal of Economic Dynamics and Control, 12(2), 231254.

Kaufmann, D., Kraay, A., \& Mastruzzi, M. (2010). The worldwide governance indicators methodology and analytical Issues. The World Bank Development Research Group Macroeconomics and Growth Team, Policy Research Working Paper 5430.

Kao, C. (1999). Spurious regression and residual-based tests for cointegration in panel data. Journal Of Econometrics, 90(1), 1-44.

Kibritçioğlu, A. (1998). İktisadi büyümenin belirleyicileri ve yeni büyüme modellerinde beşeri sermayenin yeri. Ankara Üniversitesi Siyasal Bilgiler Fakültesi Dergisi, Cilt 53, No.1-4, 207-230.

Knack, S., \& Keefer P. (1995). Institutions and economic performance: cross-country tests using alternative institutional measures. Economics and Politics, 7(3), 207-227.

Knack, S., \& Keefer P. (1997). Does social capital have an economic pay off? A cross-country investigation. The Quarterly Journal of Economics, 112(4), 1251-1288.

Kucuker, C. (2003). Türkiye iktisat kongresi büyüme stratejileri çalışma grubu. Discussion Paper, Turkish Economic Association, No. 2003/5.

La Porta, R., Lopez-de-Silanes, F., Shleifer, A., \& Vishny, R. (1998). The quality of government. The Journal of Law, Economics, and Organizations, 15(1), 239.

Leblang, D. A. (1996). Property rights, democracy and economic growth. Political Research Quarterly, 49 (1). 
Leblang, D. A. (1997). Political democracy and economic growth: Pooled cross-sectional and time series evidence. British Journal of Political Science, 27, 453-472.

Levine, R., \& Renelt, D. (1992). A sensitivity analysis of cross-country growth regressions. American Economic Review, Vol. 82, No. 4.

Levine, R. (1997). Law, finance and economic growth. Journal of Finanical Intermediation, 8, 8-35.

Levine, R., Loayza, N. \& Beck, T. (2000). Financial ıntermediation and growth: Causality and causes. Journal of Monetary Economics, Vol. 46, 31-77.

Levin, A., Lin, C. F., \& Chu, C. S. J. (2002). Unit root tests in panel data: Asymptotic and finite-sample properties. Journal of Econometrics, 108(1), 1-24.

Leschke, M. (2000). Constitutional choice and prosperity: A factor analysis. Constitutional Political Economy, 11, 265279.

Mark, N. C., Ogaki, M., \& Sul, D. (2005). Dynamic seemingly unrelated cointegrating regressions. Review of Economic Studies, 72, 797-820.

Mauro, P. (1995). Corruption and growth. The Quarterly Journal of Economics, 110, 681-713.

Mauro, P. (1998). Corruption and the composition of government expenditure. Journal of Public Economics, 69, s. 263279.

Miller, T., \& Kim, A. B. (2015). 2015 Index of Economic Freedom, Promoting Economic Opportunity and Prosperity, The Heritage Foundation and Dow Jones \& Company, Inc.

North, D. C. (2002). Kurumlar, kurumsal değişim ve ekonomik performans. (Çev. Gül Çağalı Güven), İstanbul: Sabancı Üniversitesi Yayınevi

Pamuk, Ş. (2014). Türkiye’nin 200 yılık iktisadi tarihi (I. Basım). İstanbul: Türkiye İş Bankası Kültür Yayınları.

Pedroni, P. (1999). Critical values for cointegration tests in heterogeneous panels with multiple regressors. Oxford Bulletin of Economics and Statistics, 61(1), 653-670.

Pesaran, M. H. (2007). A simple panel unit root test in the presence of cross-section dependence. Journal of Applied Econometrics, 22(2), 265-312.

Pesaran, M. H., Ullah, A., \& Yamagata, T. (2008). A bias-adjusted Im test of error cross-section Independence. The Econometrics Journal, 11(1), 105-127.

Rodrik, D. (2000). Institutions for high quality growth: What they are and how to acquire them. National Bureau of Economic Research, Working Paper. 7540.

Sachs, J. D., \& Warner, A.M. (1997). Sources of slow growth in African Economies. Journal of African Economies, 6(3), 335-76.

Scully, G.W., \& Slottje, D.J. (1991). Ranking economic liberty across countries. Public Choice, Vol. 69, No. 2, $121-152$.

Scully, W. G. (2002). Economic freedom, government policy and the trade-off between equity and economic growth. Public Choice, 113, 77-96.

Scully, W. G. (1988). The institutional frame work and economic development. The Journal of Political Economy, Vol. 96, No. 3, 652- 662 .

Siddiqui, D. A., \& Ahmed, Q. M. (2010). Institutions and economic growth: A cross country evidence. Mpra Paper, No. 19747.

Svensson, J. (1998). Investment property and political instability: Theory and evidence. European Economic Review, Vol. 42, 1317-1341.

Şanlısoy, S., \& Kök, R. (2010). Politik istikrarsızlık - ekonomik büyüme ilişkisi: Türkiye örneği (1987-2006). Dokuz Eylül Üniversitesi Iktisadi ve Idari Bilimler Fakültesi Dergisi, 25 (1), 101-125.

Tanzi, V., \& Davodi, H. (1997). Corruption, public Investment and growth. IMF Working Paper, WP/97/139.

Tarı, R. (2010). Ekonometri (6. Baskı). Kocaeli:Umuttepe Yayınları.

Tatoğlu, F. Y. (2013). Ileri panel veri analizi- Stata uygulamalı (2. Baskı). İstanbul: Beta Basım Yayım.

Taylor, M. P., \& Sarno, L. (1998). The behavior of real exchange rates during the post-bretton woods period. Journal of International Economics, 46(2), 281-312.

Uğur, M. (2011). Kurumsal kalite ve ekonomik performans: Iktisadın (yeniden) siyasallaşması mı?. Iktisat ve Toplum Dergisi, 1(9), 36-41.

Wei, S. (1997). Why is corruption so much more taxing than tax? arbitrariness kills. NBER Working Paper, Cambridge. 
Westerlund, J. (2008). Panel cointegration tests of the Fisher effect. Journal of Applied Econometrics, 23(2), $193-233$.

Westerlund, J., \& Edgerton, D. L. (2007). A panel bootstrap cointegration test. Economics Letters, 97(3), 185-190.

Whiteley, P. F. (2000). Economic growth and social capital. Political Studies, 48, 443-466.

Yapraklı, S. (2008). Kurumsal yapının ekonomik büyümeye etkisi: üst orta gelir düzeyindeki ülkeler üzerine bir uygulama. Ege Akademik Bakış, 8 (1), 301-317.

Yıldııım, S. (2010). Kurumların dinamik yapısının ekonomik büyüme üzerine etkisinin analizi. Anadolu Üniversitesi Sosyal Bilimler Dergisi, 10(3), 111-126.

Zhang, H. (2005). Corruption, economic growth and macroeconomic volatility. Perspectives, Vol. 2, No. 1.

Zouhaier, H. (2012). Institutions, investment and economic growth. International Journal of Economics and Finance, 4(2), 152. 
This Page Intentionally Left Blank 